FEAP Technical Report 98/68

April 1998

\title{
Demonstration of Electro-Osmotic Pulse Technology for Groundwater Intrusion Control in Concrete Structures
}

\author{
by \\ Vincent F. Hock, Michael K. Mclnerney, and Erik Kirstein \\ U.S. Army Construction Engineering Research Laboratories \\ Champaign, IL 61826-9005
}

Approved for Public Release; Distribution Is Unlimited. 


\section{Foreword}

This study was conducted for U.S. Army Center for Public Works (USACPW) under the Facilities Engineering Application Program (FEAP); Work Units FMF95 and FL-F96, "A Demonstration of Electro-Osmotic Pulse (EOP) Technology for Control of Seepage in Concrete Structures." The technical monitors were Fidel Rodriguez, CECPW-EB and Malcolm McLeod, CECPW-ES

The work was performed by the Materials Science and Technology Division (FL-M) of the Facilities Technology Laboratory (FL), U.S. Army Construction Engineering Research Laboratories (CERL). The CERL principal investigator was Vincent F. Hock. The contributions of the following CERL personnel are gratefully acknowledged: Hannon Maase and Henry Cardenas. The assistance provided by Frank Cooper, ATZJ -PWO, Fort J ackson, SC; Gary Reasoner, SIOMC-DEO, McAlester Army Ammunition Plant; Dr. Charles Lozar of Architects Equities Research Group; and Roger Hayes, Arild Ottersen, Egil Bjerke, and Micheal Connor, Drytronic (formerly know as Dry-Tec of North America), was essential to the successful completion of this work. Dr. Ilker R. Adiguzel is Acting Chief, CECER-FL-M; Larry M. Windingland is Acting Operations Chief, CECER-FL; and Dr. Alan W. Moore is the responsible Technical Director, CECER-FL. The CERL technical editor was William J . Wolfe, Technical Resources.

COL J ames A. Walter is Commander and Dr. Michael J. O'Connor is Director of CERL. 


\section{Contents}

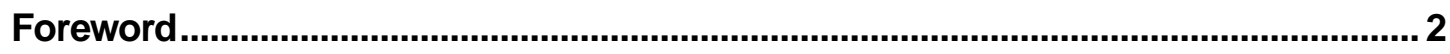

List of Figures and Tables........................................................................ 4

$1 \quad$ Introduction.................................................................................................... 5

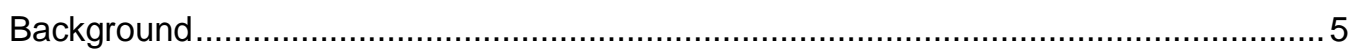

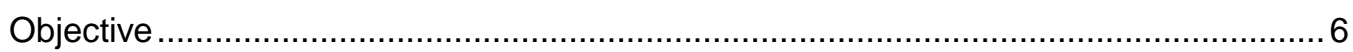

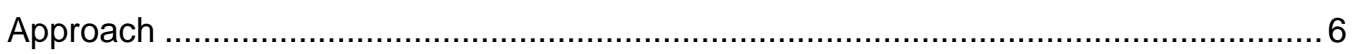

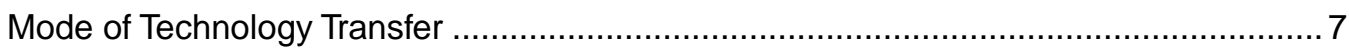

$2 \quad$ Description of EOP Technology...................................................................... 8

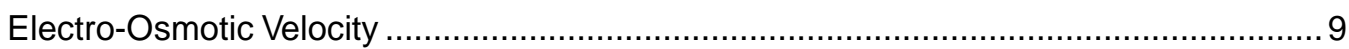

Pulsating Electro-Osmosis.......................................................................................... 11

$3 \quad$ Pre-Installation Site Inspection ....................................................................... 13

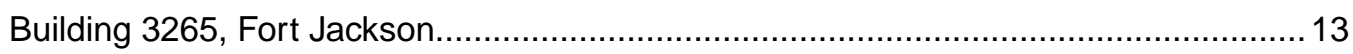

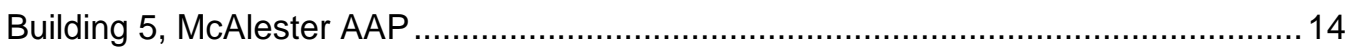

$4 \quad$ EOP System Installation and Field Testing ..................................................... 16

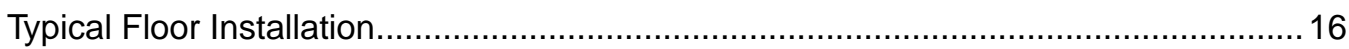

Typical Wall Installation ...................................................................................... 17

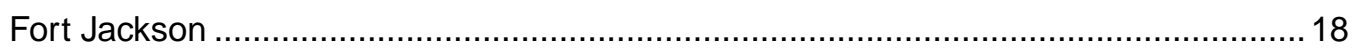

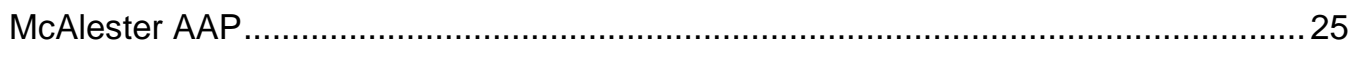

$5 \quad$ Cost/Benefit Analysis ............................................................................................ 30

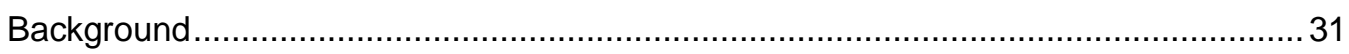

Estimating the Cost of the Standard Approach ..................................................... 33

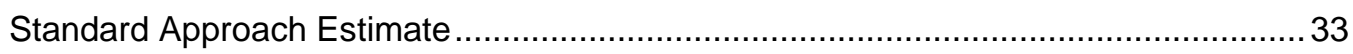

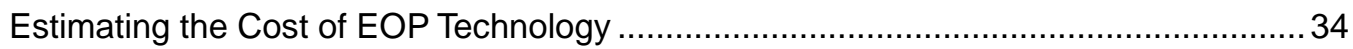

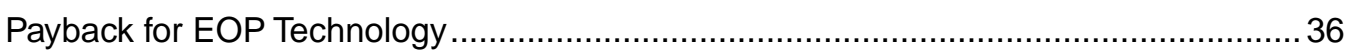

$6 \quad$ Conclusions and Recommendations ...................................................... 37

References..................................................................................................................... 38

Appendix: Data Logged From Building 5, McAlester AAP, OK ................................39

Distribution 


\section{List of Figures and Tables}

\section{Figures}

1 hovement of cations in a soil pore by electro osmosis............................................

2 Arresting contaminant migration in an earthen landfill liner. ................................... 10

3 Generic EOP voltage waveform....................................................................... 12

4 Cross section showing the EOP process ......................................................... 12

5 Standing water in basement of Building 3265, Fort Jackson. .................................... 14

6 Standing water in basement of Building 5, McAlester AAP. ................................. 15

7 Demonstration project sign. .......................................................................................... 18

8 Rubber graphite anode. ........................................................................ 19

9 Layout of EOP installation at Fort Jackson. ...................................................... 20

10 Mr. Cooper demonstrating the operation of the EOP control unit............................20

11 Locations of moisture meters and rebar specimens in basement of Building 3265....22

12 Hydrograph line from monitoring well Fort Jackson. ............................................24

13 Basement of Building 5 at McAlester AAP............................................................. 26

14 EOP unit output waveform recorded at McAlester AAP, November 1996 ................28

15 Power consumption of EOP system in relation to relative humidity in the wall. ............30

16 Water table with respect to the basement floor for McAlester AAP. .......................... 30

17 Dry floor in basement of building 3265, Fort Jackson, following EOP application. .......32

18 Dry floor in basement of Building 5, McAlester AAP, following EOP application...........32

Tables

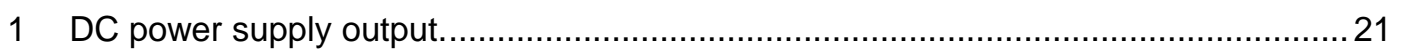

2 Concrete moisture readings in Building 3265 ..........................................................22

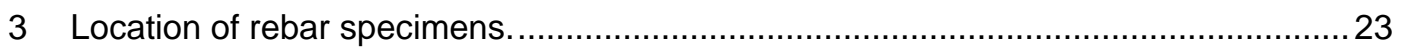

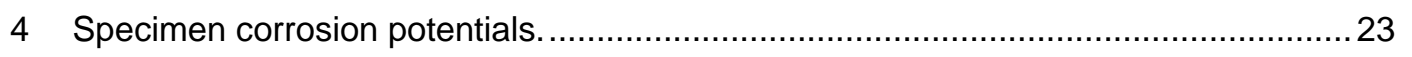

$5 \quad$ Average monthly precipitation data, Columbia, SC........................................... 25

6 Standard approach cost estimate . ............................................................................ 35

7 Costs of EOP technology installation........................................................... 35

8 Eateutation of EOP-System Basect on minstallect Costs and Hf of Wall.........................35 


\section{Introduction}

\section{Background}

Groundwater intrusion through a building's foundation (i.e., a "wet basement problem") can cause serious damage that is expensive to correct. Basement dampness can ruin expensive equipment, e.g., Heating Ventilation, and AirConditioning (HVAC) equipment, which is often located in basement space; can increase maintenance requirements (through frequent repainting or cleaning to combat mold growth); and can make affected areas uninhabitable or even unusable (e.g., as a result of poor air quality).

In fact, a properly designed original foundation with appropriate damp-proofing will avoid most water problems. However, in older buildings, such as those common on U.S. Army installations, severe damp-basement problems call for immediate action to mitigate water damage. In selective problem areas, the usual approach is to "trench and drain," in other words, to: (1) excavate to expose the wall area and the base of the foundation, and (2) replace the dampproofing on the wall surfaces and install a drain tile system around the building or affected area. This expensive process is further complicated by the fact that most contractors limit their warrantees against future seepage in areas with high water tables.

Electro-osmotic pulse (EOP) technology offers an alternative that can mitigate some water-related problems from the interior of affected areas without the cost of excavation. The EOP alternative can further mitigate corrosion damage to mechanical equipment along with humidity and mold problems.

Electro-osmosis is not a new discovery although new applications for this technology are still being developed. In 1809, F.F. Reuss originally described electro-osmosis in an experiment that showed that water could be forced to flow through a clay-water system when an electric field was applied to the soil. Research since then has shown that flow is initiated by the movement of cations (positively charged ions) present in the pore fluid of clay or similar porous media such as concrete; the water surrounding the cations moves with them. Electroosmosis has been used in civil engineering to dewater dredgings and other high- 
water content waste solids, consolidate clays, strengthen soft sensitive clays, and increase the capacity of pile foundations. It has also received significant attention in the last 5 years as a method to remove hazardous contaminants from groundwater or to arrest water flow.

A system has been developed to apply electro-osmotic pulse (EOP) technology commercially within concrete structures by applying a pulsating electric field combined with an off-period. The pulsating electro-osmotic sequence consists of a pulse of positive vol tage (as seen from the dry side of the concrete wall), a pulse of negative voltage, and a period of rest when no voltage is applied. The pulse of positive voltage has the greatest duration. The amplitude of the signal is typically on the order of 20 to 40 volts DC. The electrical pulse causes cations (e.g., $\mathrm{Ca}^{++}$) and associated water molecules to move from the dry side towards the wet side against direction of flow induced by the hydraulic gradient, thus preventing water penetration through buried concrete structures. Field testing tests the feasibility and cost effectiveness of EOP technology, in comparison with conventional ("trench and drain") dampness mitigation techniques, at selected Army installations.

\section{Objective}

The objective of this study was to demonstrate and document the effectiveness of EOP technology to control groundwater intrusion in concrete structures at Fort J ackson, SC and McAlester Army Ammunition Plant (AAP), OK.

\section{Approach}

1. In the summer of fiscal year 1994 (FY94), Bldg. \#3265 at Fort J ackson, SC was chosen as a candidate basement structure due to its history of water seepage.

2. In August 1994, an EOP system was installed in the basement of BIdg. 3265.

3. The effectiveness of the installed EOP system was monitored over a 2-year period (FY95-96), including the following parameters: (a) power supply output, (b) effect of EOP on the corrosion potential of rebar, (c) concrete moisture, (d) water table level, and (e) monthly rainfall.

4. A second EOP system was installed in Building 5 at MCAlester during J uly 1996. A remote monitoring system, including a water table monitoring well, was installed at the same time. The monitoring well was installed by the 
Tulsa District, Corps of Engineers (COE) for the U.S. Army Construction Engineering Research Laboratories (CERL).

5. Most data from the McAlester site is downloaded on a periodic basis to CERL through a dedicated modem and phone line. The site is being monitored for 12 months (FY96-97) to validate seasonal water table levels. Life-cycle costs and benefits will be calculated and technology transfer materials will be completed during FY 97.

\section{Mode of Technology Transfer}

A FEAP Ad Flyer and User Guide will be published, to be distributed through the U.S. Army Center for Public Works (USACPW), Alexandria, VA. The user guide will include specifications and procedures for equipment selection, procurement, and use. The EOP technology will also be presented in CERL's annual corrosion and building technology courses and articles will be published in the USACPW's Public Works Digest, FEAP Bulletin, and related trade journals such as the National Association of Corrosion Engineers' (NACE's) Materials Performance. Lastly, the EOP technology will be presented by USACPW during site assistance visits. 


\section{Description of EOP Technology}

If ions of one sign are preferentially adsorbed at a solid solution interface, a net charge or electric potential difference develops across the interface. This phenomenon is referred to as electro-osmosis. (The basic physics and chemistry of electro-osmosis can be found in several textbooks and treatises: W.H. Hamill et. al. 1966; S. Glasstone, 1946; K.P. Tikhomolova, 1993) It was found that when a potential difference is applied to electrodes immersed into an electrolyte solution on opposite sides of a porous plug or fine capillary tube, a flow of the solution results. Similarly, when a solution is forced through such a barrier by hydrostatic pressure, a potential difference develops between the solution on one side of the barrier and that on the other. This is called the streaming potential.

Descriptions of these phenomena are based on the concept of electric double layer. A layer of ions (which is approximately a single ion in thickness) of one sign is firmly adsorbed on the solid surface or particle, the sign of the charge depending on the nature of the surface and other conditions. The region as a whole is electrically neutral, and an equal number of opposite electric charges are present in an adjacent ionic atmosphere which, as the term implies, becomes more attenuated as distance from the surface increases. This is called the diffuse layer. When the solid surface and fluid are in relative motion, there exists a velocity gradient, and a thin film of solution, together with the ions it contains, is immobilized near the wall. Part of the ion atmosphere moves with the solution, and part (together with adsorbed ions) effectively belongs to the surface. As a result, the liquid phase and the wall have different net electric charge, and the application of an external electric field produces relative motion.

For example, electro-osmosis occurs in clay soils when cations in the diffuse layer are driven by the application of an external electric field. As a result, a velocity field in the pore fluid develops (Figure 1). The velocity distribution changes rapidly near the particle's surface, but then becomes flat at the edge of the diffuse layer. Hence, electro-osmotic flow appears as plug flow through the pores of soil. 


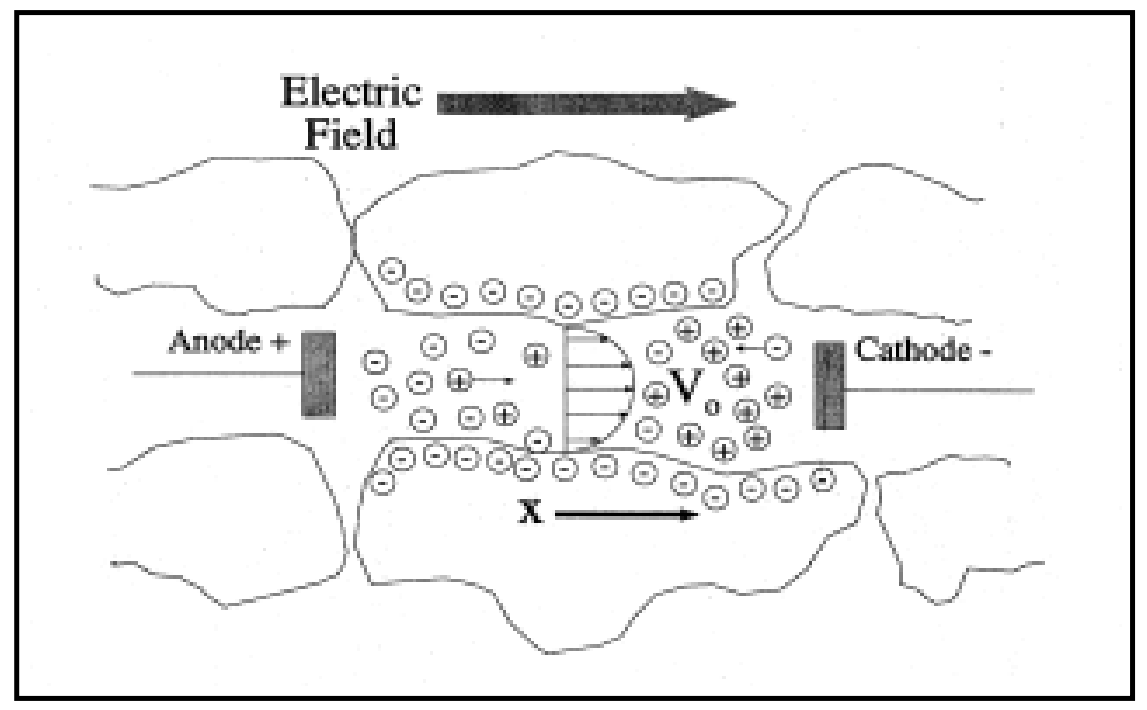

Figure 1. Movement of cations in a soil pore by electro osmosis.

\section{Electro-Osmotic Velocity}

The velocity profile reaches a constant value $\left(V_{0}\right)$ a short distance from the particle's surface. To determine $\mathrm{V}_{\mathrm{o}}$, a steady-state equation of motion is:

$$
\mu \frac{\partial^{2} V_{x}}{\partial y^{2}}+E_{x} \varepsilon \frac{d^{2} \phi}{d y^{2}}=0
$$

where:

$\mu=$ the viscosity of the solution

$\mathrm{V}_{\mathrm{x}}=$ the velocity of the solution parallel to the particle surface

$\mathrm{y}=$ the distance orthogonal to the particle surface

$\mathrm{E}_{\mathrm{x}}=$ the externally applied electric field gradient

$\varepsilon=$ the permitivity of the solution

$\phi=$ the electrical potential gradient.

By the Debye-Hückel approximation, $\phi$ is written as:

$$
\phi=\xi \exp \left(-y \sqrt{\frac{2 \mathrm{n}_{\mathrm{i}}^{\infty} \mathrm{Z}_{\mathrm{i}}^{2} \mathrm{~F}^{2}}{\varepsilon \mathrm{RT}}}\right)
$$


where:

$\xi=$ the zeta potentiall

$n_{i}^{\infty}=$ the concentration of constituent $\mathrm{i}$ in free solution

$\mathrm{Z}_{\mathrm{i}}=$ the equivalents/mole of constituent $\mathrm{i}$

$\mathrm{F}=\mathrm{F}$ araday's constant

$\mathrm{R}=$ the universal gas constant

$\mathrm{T}=$ the absolute temperature.

When Eq 1 is integrated with the boundary conditions,

$$
\begin{array}{ll}
V_{x}=0 & \text { at } y=0 \\
V_{x}=V_{0} & \text { at } y>>0
\end{array}
$$

[Eq 3]

The vel ocity $\mathrm{V}_{\mathrm{o}}$ is then obtained:

$$
V_{o}=\frac{\varepsilon \xi}{\mu} E_{x}
$$

[Eq 4]

Of the four independent variables in $\mathrm{Eq} \mathrm{4}_{\mathrm{x}} \mathrm{E}_{\mathrm{x}}$ can be controlled to redirect the movement of the solution. Figure 2 shows how $E_{x}$ can be controlled for this purpose. Without electro-osmosis, the flux of species i consists of an advective flux $\left(\mathrm{J}_{\mathrm{ai}}\right)$ and a diffusive flux $\left(\mathrm{J}_{\mathrm{di}}\right)$.

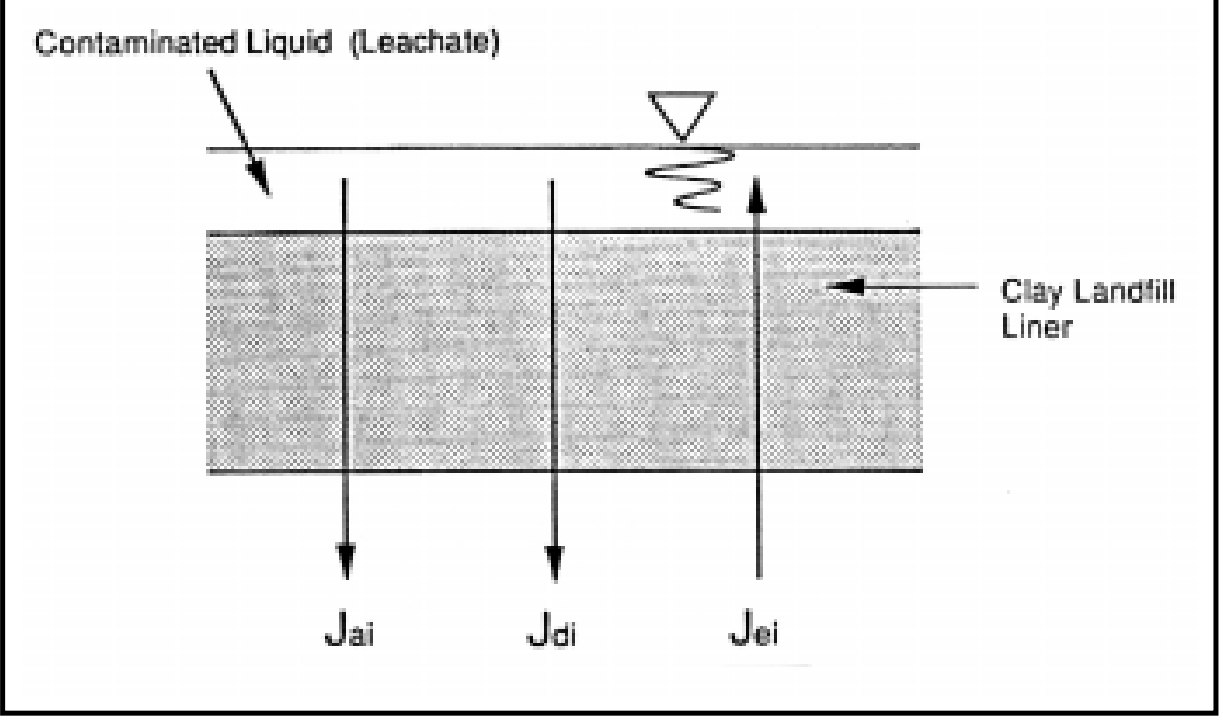

Figure 2. Arresting contaminant migration in an earthen landfill liner.

\footnotetext{
*The difference of potential between the plates of a hypothetical capacitor used to model the diffuse layer.
} 
Both of these fluxes drive contaminants downward. An electro-osmotic flux $\left(J_{e}\right)$ can be applied to counter these fluxes:

$$
J_{e i}=n_{e} V_{o} C_{i} \approx n_{e} n_{i} \frac{\varepsilon \xi}{\mu} E_{x}
$$

where $C_{i}$ is the concentration of constituent $i$, and $n_{e}$ is the effective soil porosity.

To stop or reverse the movement of constituent $\mathrm{i}, \mathrm{E}_{\mathrm{x}}$ is adjusted so that:

$$
J_{e i} \geq J_{a i}+J_{d i}
$$

[Eq 6]

\section{Pulsating Electro-Osmosis}

The pulsating electro-osmotic technique consists of a positive voltage pulse, a negative voltage pulse, and a period when no voltage is applied. Figure 3 shows an example waveform for the pulsating electro-osmotic pulse or EOP system. The positive voltage pulse has the longest interval and the negative voltage pulse has the shortest interval. As a result of this, the pore fluid moves (on the average) in one direction.

Currently, the reasons for the increased performance of the EOP system over standard DC electro-osmosis for drying concrete are not well understood. However, it is speculated that the change in polarity results in the reversal of some of the chemical reactions occurring during electrolysis. It is also believed that the rest phase (no applied voltage) allows the system to equilibrate. As a result of these effects, undesirable side effects such as acid production and increased corrosion are avoided. Also, use of a pulse sequence might prevent the concrete from becoming too dry.

An EOP system is realized by inserting anodes (positive electrodes) into the concrete wall or floor on the inside of the structure and by placing cathodes (negative electrodes) in the soil directly outside the structure. The density of the anode and cathode placement is determined from an initial resistivity test of the concrete and soil. The objective is to achieve a certain current density in the concrete. Figure 4 illustrates the EOP process. 


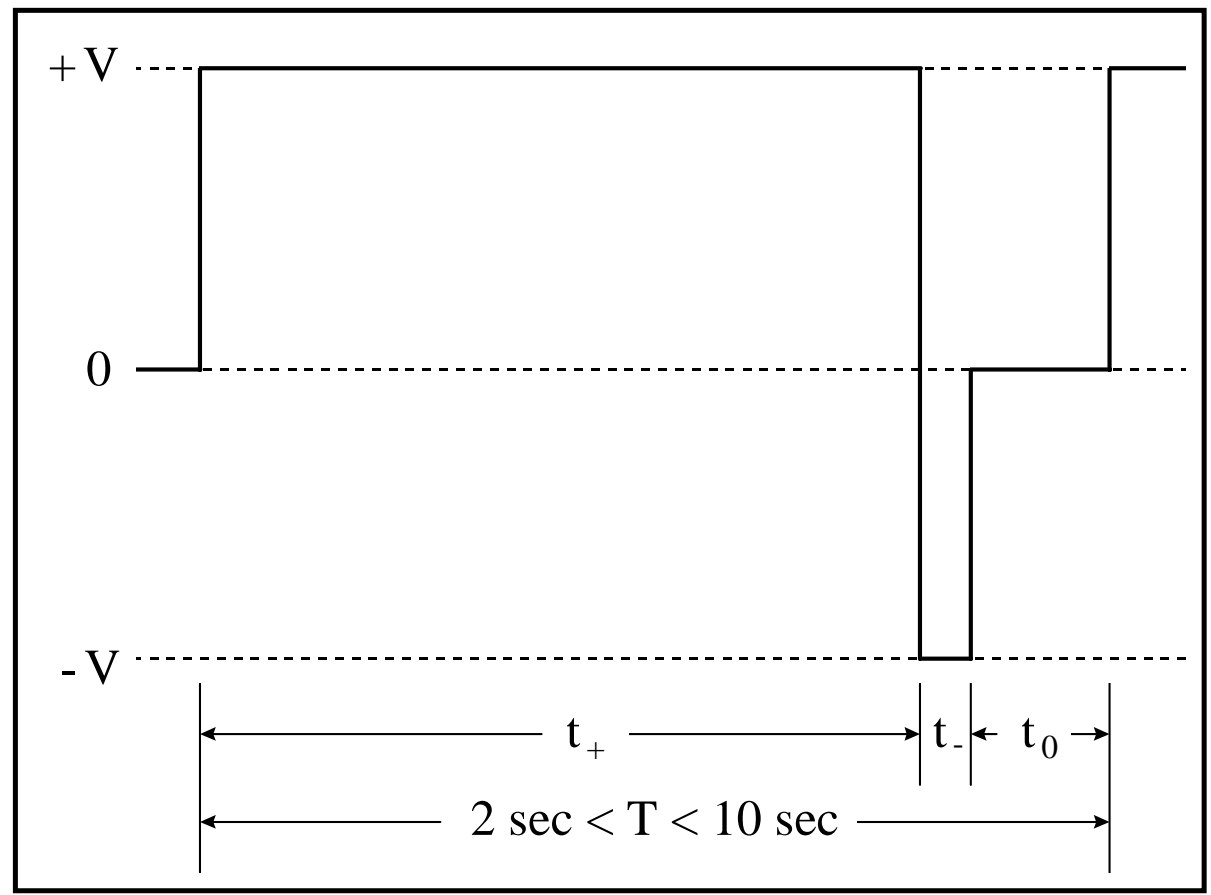

Figure 3. Generic EOP voltage waveform.

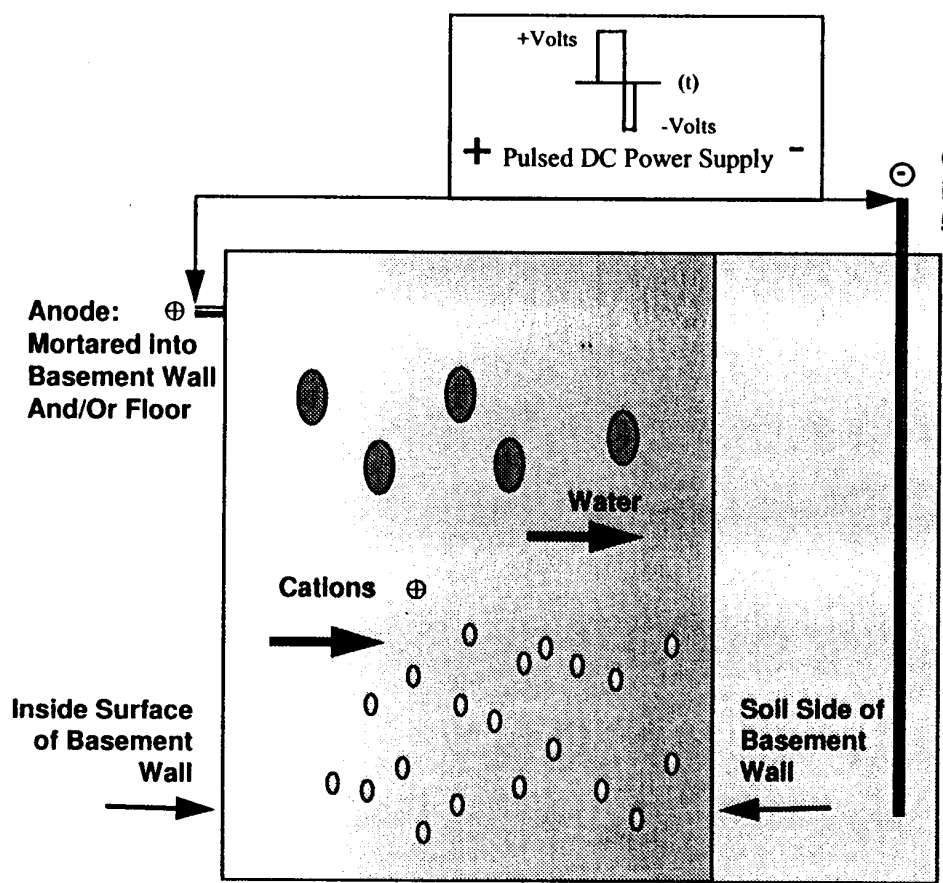

Cathode: Copper Ground

Rod Embedded in Soll 3 to

5 feet from Basement Wall

Anode:

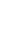

DC electric field promotes movement of cations (+), and associated water molecules towards the cathode. This creates counterflow and associated osmotic pressure differential across concrete section. The shorter time duration of the negative pulse allows some moisture to be retaincd within the concrete matrix preventing overdrying of the concrete.

Basement Wall Cross Section

Figure 4. Cross section showing the EOP process. 


\section{Pre-Installation Site Inspection}

Two sites were selected for the EOP technology demonstration: (1) Fort J ackson, SC and (2) McAlester AAP, OK. In both cases, the location of the groundwater intrusion was through the floor and walls of the poured concrete basements. The EOP system was installed in Building 3265 at Fort J ackson and Building 5 at McAlester.

Groundwater intrusion into basements leads to various problems, including concrete degradation, rebar corrosion, and personal health and safety hazards. Also, because of the high humidity conditions associated with ever present standing water, corrosion of peripheral building mechanical equipment, pumps, boilers, and associated systems is accelerated, minimizing the opportunities for extending the useful life of those facilities. Lastly, current management practices for the disposal of standing or subterranean water raises additional environmental concerns. For instance, water pumped from a sump pit in a mechanical room often has to be treated as "mixed waste" because of oil droppings and lubricants mixing with water from the mechanical systems.

\section{Building 3265, Fort Jackson}

Building 3265 had a history of water seepage into the concrete basement mechanical room. The mechanical room had experienced water levels within the structure as high as $14 \mathrm{in}$. . water. In addition, there was seepage from cracking in the wall, efflorescence, and poor air quality as a result of the high indoor humidity. This seepage initiated corrosion of the mechanical equipment located in the basement. Figure 5 shows the standing water in the basement mechanical room before the EOP system installation.

\footnotetext{
${ }^{*} 1 \mathrm{in} .=25.4 \mathrm{~mm} ; 1 \mathrm{ft}=0.304 \mathrm{~m}$.
} 


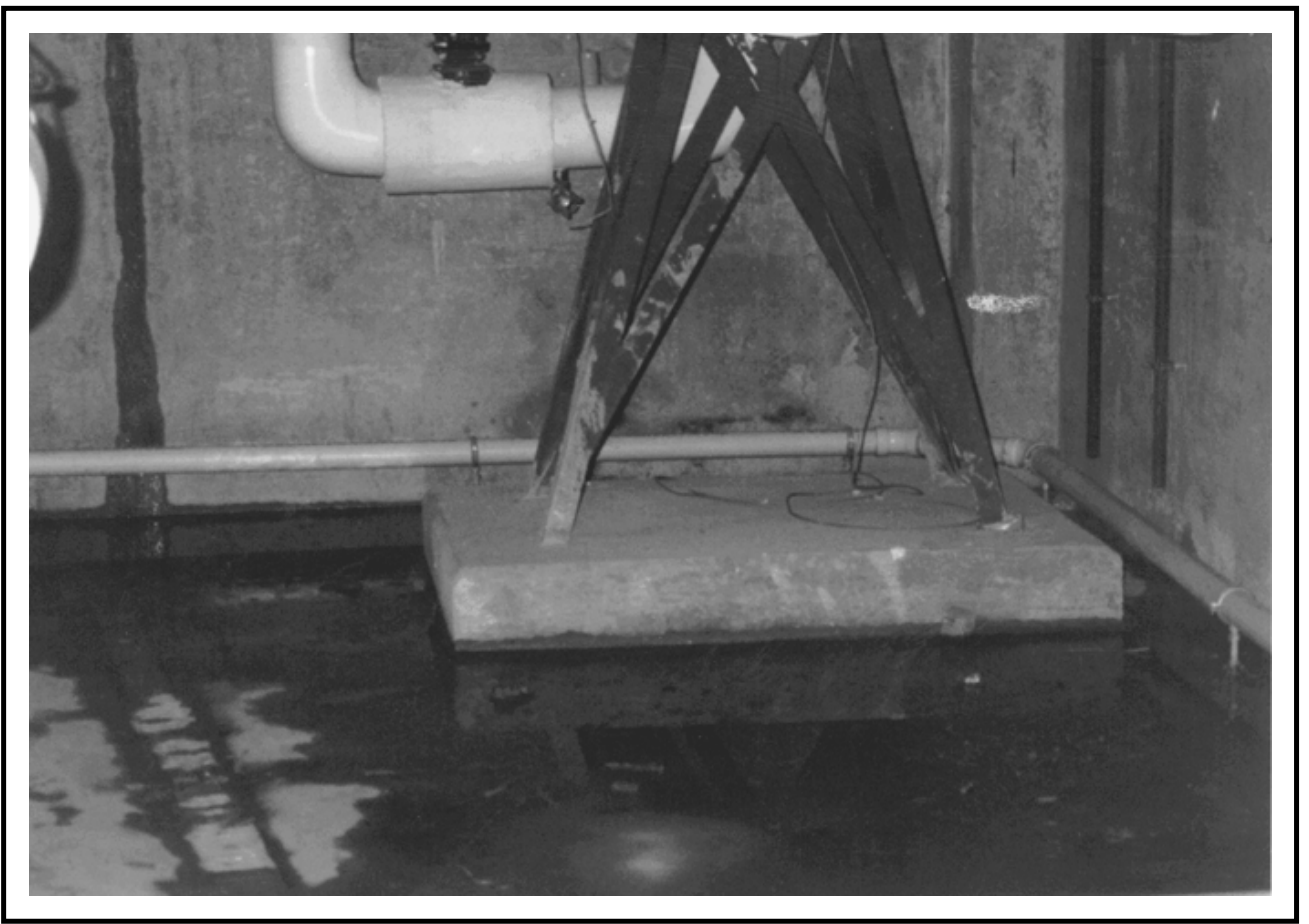

Figure 5. Standing water in basement of Building 3265, Fort Jackson.

\section{Building 5, McAlester AAP}

The basement of Building 5 had standing water in several areas. Problems similar to the basement at Fort J ackson were prevalent: water seepage from cracking in the wall, efflorescence, and high indoor humidity (70 percent). The reduction of the indoor air humidity through the EOP system is very important, as one of the rooms is the Industrial Hygiene Office, occupied by an individual 40 hours a week. Standing water can be seen in one of the corners of the office (Figure 6). 


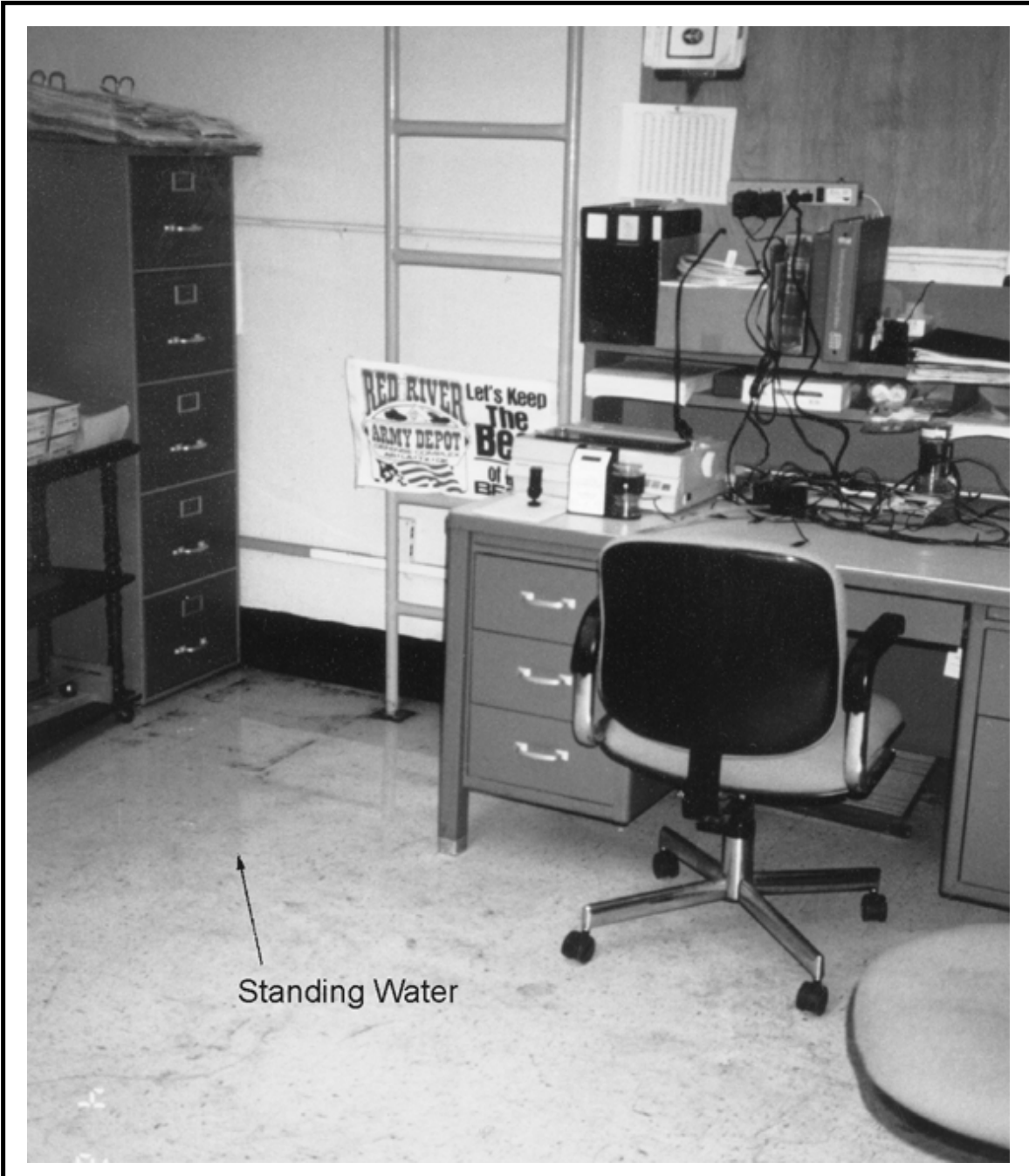

Figure 6. Standing water in basement of Building 5, McAlester AAP. 


\section{EOP System Installation and Field Testing}

\section{Typical Floor Installation}

Below is a generic procedure for a typical floor installation of the EOP system as used by Drytronic of N orth America:

1. Repair any cracks or voids where obvious water penetration is occurring with either mortar, grout, foams, or epoxies (depending on conditions). These materials must be compatible with the EOP System.

2. A resistivity test of the concrete and soil is done to determine both the pattern of the anode cable (positive electrode) and the number and locations of the cathodes (negative electrodes). One anode and cathode are temporarily installed in the concrete floor and soil, respectively, and are connected to an EOP Control Unit. The voltage and current in the circuit are measured and used to compute the concrete/soil resistivity. A lower resistance requires a more dense anode cable pattern and/or a higher number of cathodes. (The objective is to achieve a certain current density in the concrete.)

3. Grooves are cut into the floor in the pattern that was determined from resistivity testing. These grooves will vary in width and depth depending on the type of anode cable to be installed in the floor. The anode cable is placed in these floor grooves.

4. Cathodes are installed bel ow the floor and, if necessary, outside the structure. Floor installation is done by drilling holes through the floor at the locations determined by resistivity testing. The cathodes can then be installed into the soil through the floor. Cathodes can be installed outside the structure by driving them into the ground like an electrical ground rod or by installing through the wall in a manner similar to the floor installation.

5. The EOP Control Unit is mounted in a location suitable to both the user and the installer. 
6. Wiring is run from the EOP Control Unit to both the wire anodes and the cathodes. By using properly insulated wires, these wires can be embedded in the grooves that are in the floor.

7. After all wiring is placed in the grooves, mortar is used to fill the grooves to within $1 / 4$ to $1 / 2$ in. of the surface. Then a leveling agent is used to completely fill the groove and level the surface.

8. The EOP Control Unit is turned on, adjusted, and calibrated. The system is now operational.

\section{Typical Wall Installation}

Below is a generic procedure for a typical wall installation of the EOP system as used by Drytronic of North America:

1. Repair any cracks or voids where obvious water penetration is occurring with either mortar, foams, or epoxies depending on conditions. These materials must be compatible with the EOP System.

2. A resistivity test of the concrete and soil is done to determine both the number and locations of the anodes (positive electrodes) and the cathodes (negative electrodes). One anode and cathode are temporarily installed in the concrete wall and soil, respectively, and are connected to an EOP Control Unit. The voltage and current in the circuit are measured and used to compute the concrete/soil resistivity. A lower resistance requires a higher number of anodes and/or a higher number of cathodes. (The objective is to achieve a certain current density in the concrete.)

3. Once an anode distribution is determined, 3/4-in. holes are drilled into the concrete wall where needed. The depth of these holes is determined by the thickness of the concrete. The holes are drilled in a pattern that will avoid making contact with the rebar. Anodes are placed in the $3 / 4$-in. holes and packed with a mortar compatible with the EOP System.

4. Cathodes are installed. The cathodes may be placed around the exterior of the building when conditions permit, or may be installed through the concrete wall. Cathodes can be installed outside the structure by driving them into the ground like an electrical ground rod or by installing through the wall in a manner similar to the floor installation.

5. The EOP Control Unit is mounted in a location suitable to both the user and the installer. 
6. Wiring is run from the EOP Control Unit to both the anodes and cathodes. This wire may be installed in several different ways:

a. Surface mounted and enclosed in plastic wire mold

b. Enclosed in either metal or plastic conduit and junction boxes

c. Buried in the concrete wall with the grooves patched with mortar, creating a flush wall finish.

7. The EOP Control Unit is turned on, adjusted and calibrated. The system is now operational.

\section{Fort Jackson}

The first Army EOP demonstration was conducted at Fort J ackson, SC, during FY94. To advertise this demonstration, a sign was placed near the installation. Figure 7 shows Mr. Frank Cooper, Chief, Operations and Maintenance Division, Directorate of Public works Fort J ackson standing next to the sign.

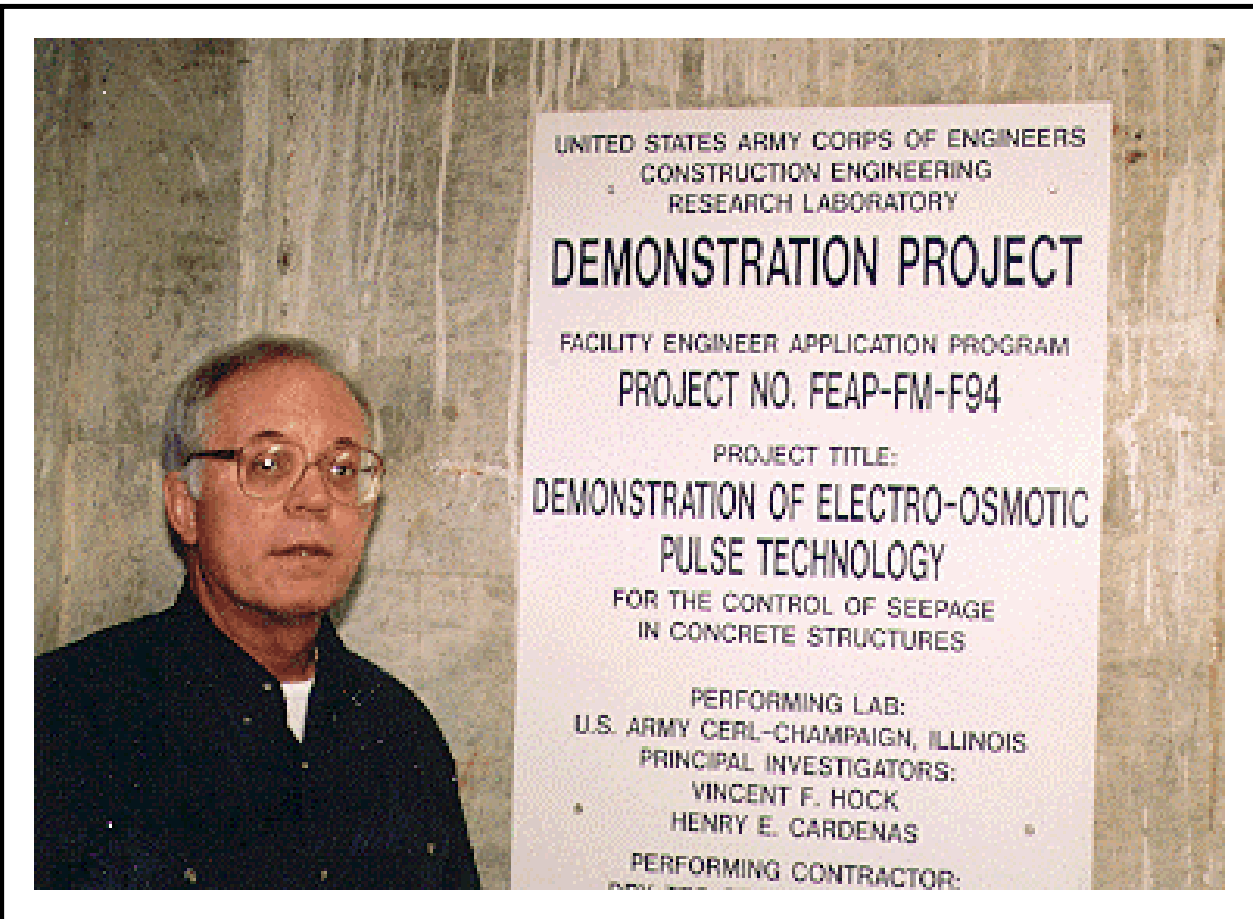

Figure 7. Demonstration project sign. 


\section{Installation}

On arrival at the site on 22 August 1994, the technicians from Drytronic (the company contracted for the installation of the EOP system) found that approximately one-third of the floor was covered with water, in some areas to a depth of 1 in. Before installing the EOP system, the larger cracks were waterproofed by chiseling out those areas above the water table where there were cracks and resealing those areas with hydraulic cement. For the EOP system, 83 rubber-graphite electrodes (anodes) were coated with a graphitemortar mixture and inserted into holes drilled into all four walls, approximately 5 in. from the floor and 18 in. apart. Figure 8 shows a rubber-graphite anode. Twenty-four ft of rubber-graphite conductive cable was installed around the base of a concrete pad that supported steel water tanks in the room. Three copper grounding rods (cathodes) were driven into the exterior ground.

A Drytronic self-monitoring EOP Control Unit was mounted on one wall and all wiring from the anodes and cathodes was enclosed and wired into the unit. Additional work included patching holes in wall areas where equipment had been removed, and removing unneeded steel pipes and conduit. The control unit was activated on 26 August 1994.

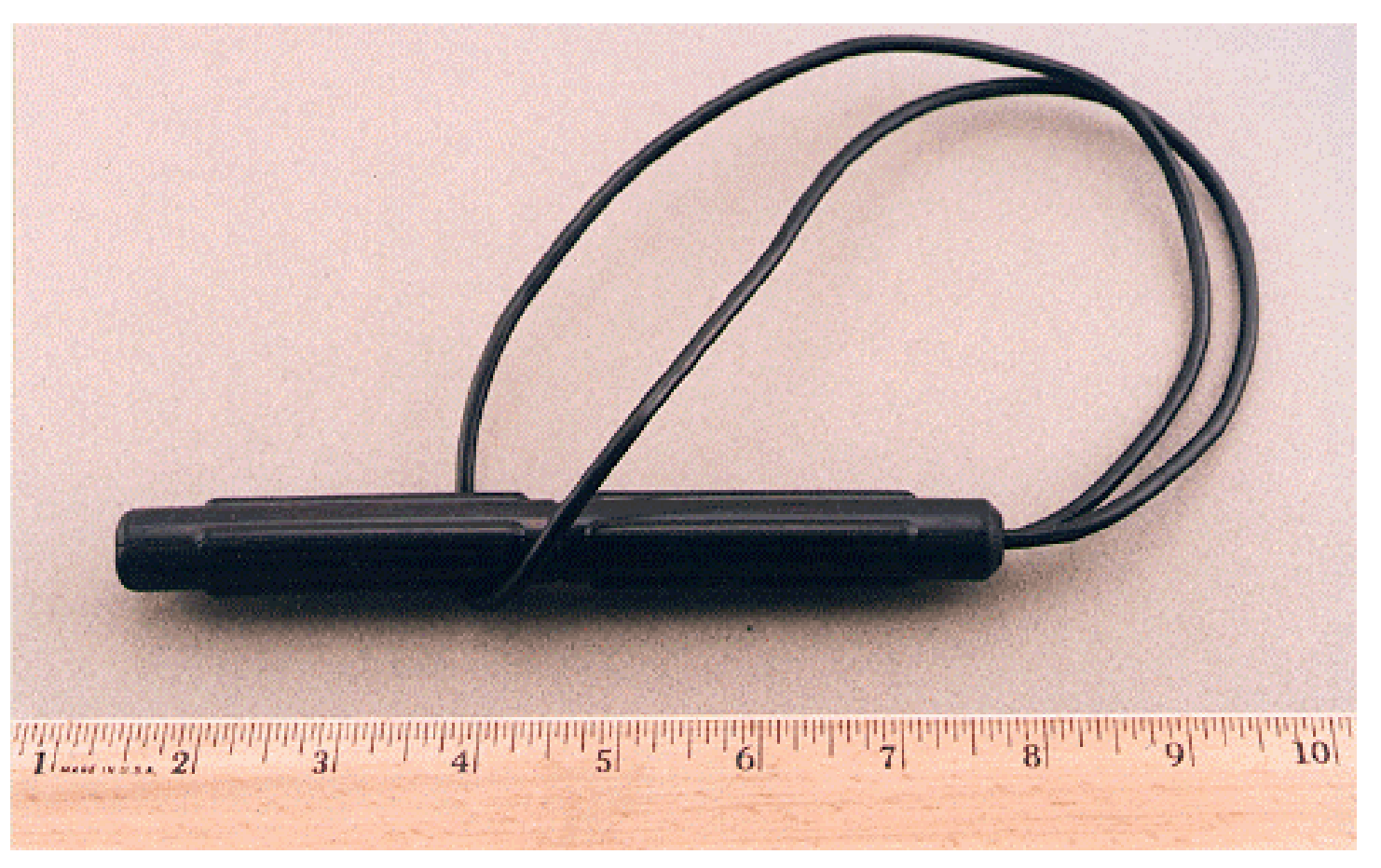

Figure 8. Rubber graphite anode. 
Figure 9 shows the basement mechanical room schematically, and highlights the locations of the EOP Control Unit, anodes, and cathodes. Figure 10 shows Mr. Cooper demonstrating the operation of the EOP control unit.

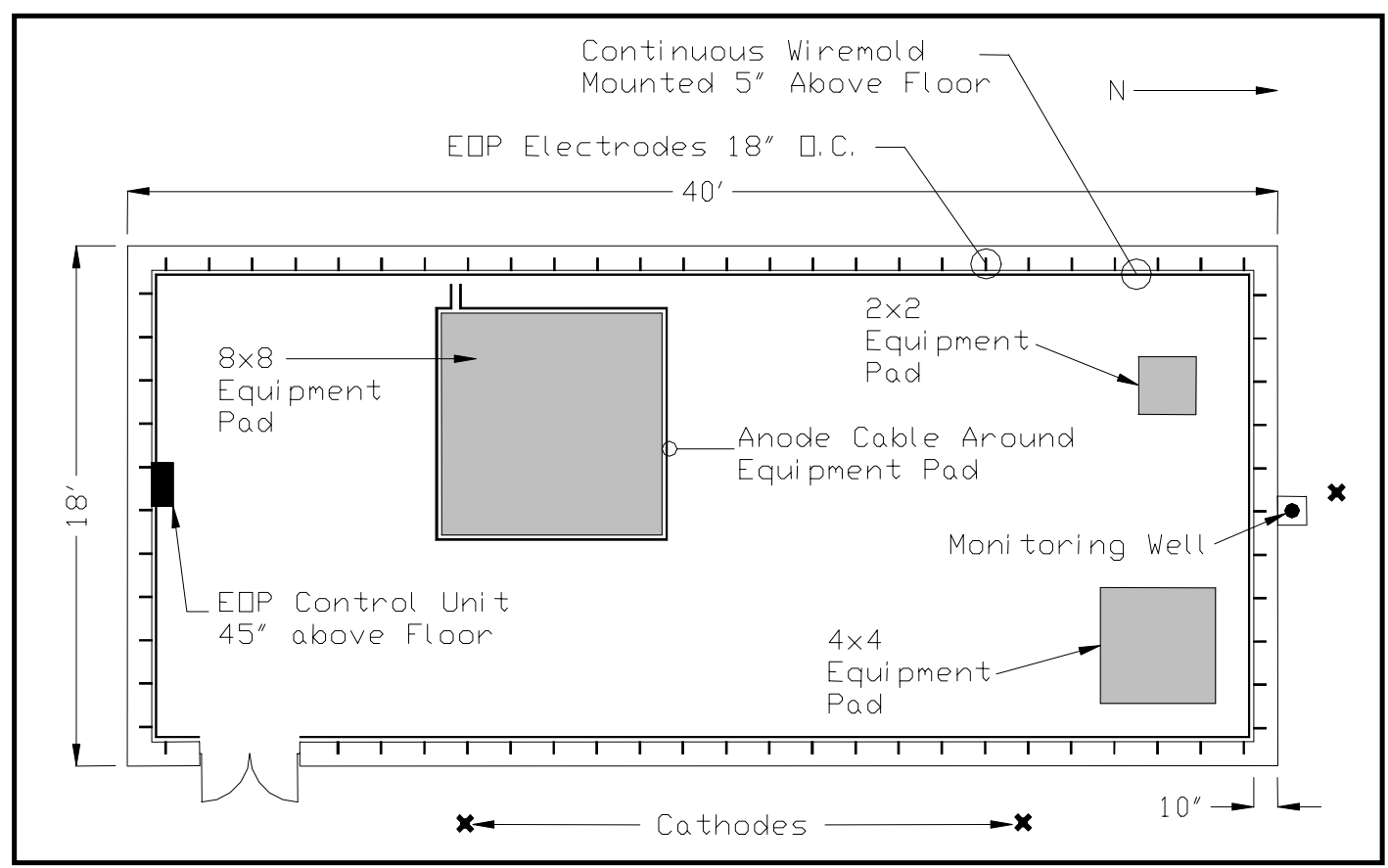

Figure 9. Layout of EOP installation at Fort Jackson.

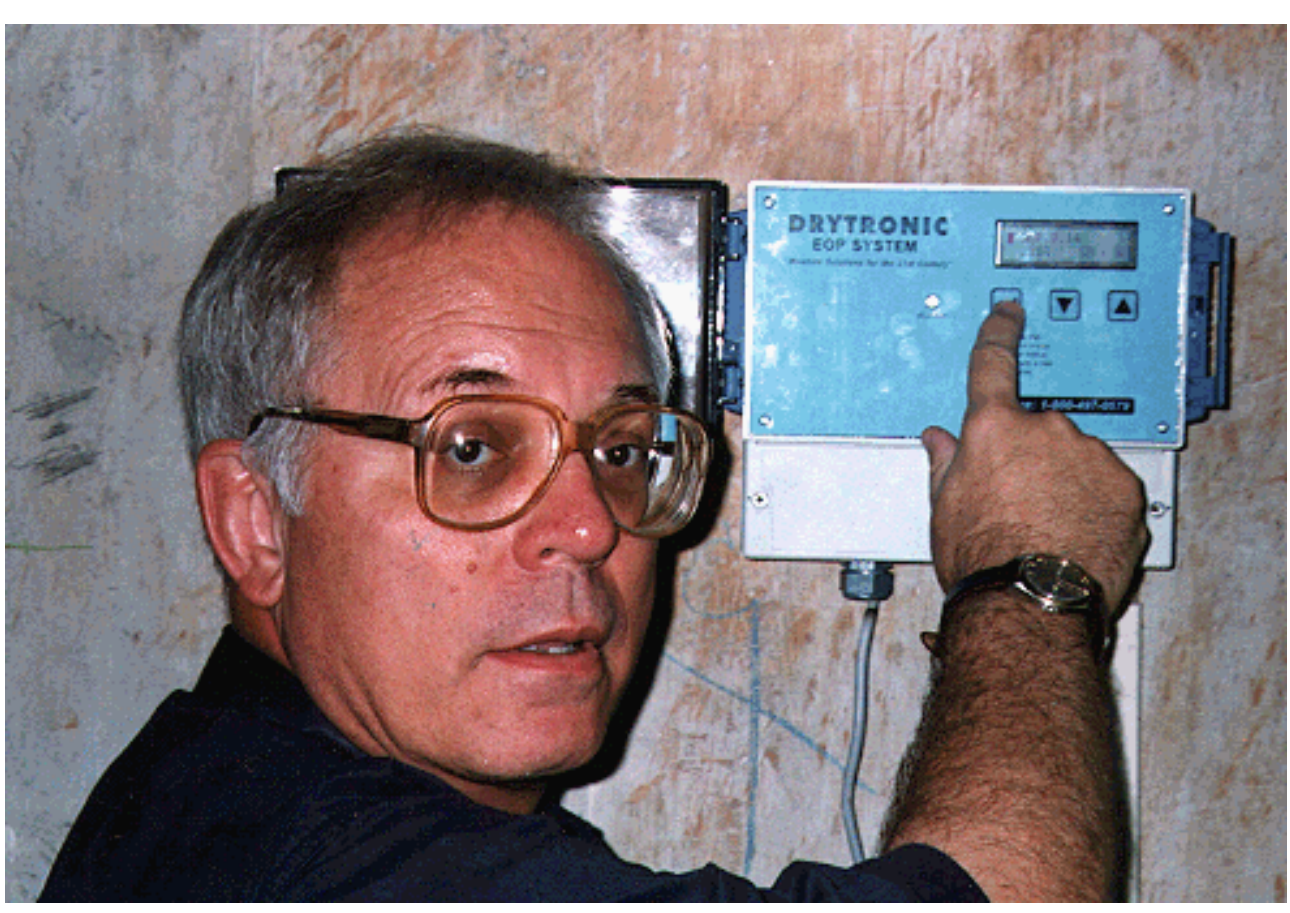

Figure 10. Mr. Cooper demonstrating the operation of the EOP control unit. 


\section{EOP Control Unit Operating Data}

The EOP power supply is configured to first generate a long duration positive direct current (DC) pulse between the anodes and cathodes followed by a much shorter negative pulse. The final pulse in the sequence is a zero voltage, or "rest," pulse. The pulse sequence and the individual pulse lengths are both programmable. Typical settings are 6 seconds for the pulse sequence, 4.8 seconds (or 80 percent of the sequence length) for the positive pulse, 0.3 seconds (or 5 percent of the sequence length) for the negative pulse, and 0.9 seconds (or 15 percent of the sequence length) for the rest period. Figure 3 shows an example EOP voltage waveform.

The EOP Control Unit power supply current load was within acceptable limits, varying from $0.75 \mathrm{Amps}$ for a high humidity environment to less than $0.2 \mathrm{Amps}$ for a low humidity environment. This is a result of the characteristics of the EOP system. The EOP power supply produces a voltage pulse of constant amplitude (i.e., a constant voltage power supply). The resistivity of the concrete is inversely proportional to the amount of water present in the concrete. As the water is slowly driven out, the resistivity of the concrete increases, dropping the current load of the power supply, since current is inversely proportional to resistance (Ohm's Law). Table 1 shows the current and voltage outputs of the EOP power supply. The slight increase in output current is due to the higher water table during J uly and August 1996.

\section{Concrete Humidity Readings}

During installation of the EOP system, concrete moisture readings were taken at different locations on the walls. The exact locations of these readings (and the locations of the three rebar specimens mentioned in the following section) are shown in Figure 11. Table 2 lists the moisture measurements taken at three different times: (1) at the time of installation, (2) at the 5-month performance check, and (3) 2 years after installation. The data are presented as percent relative humidity. All measurements were made at the concrete surface, not internally. The most suitable humidity for concrete structures is $\approx 70$ percent. Note the direct correspondence between the power supply current (Table 1) and the concrete humidity (Table 2).

Table 1. DC power supply output.

\begin{tabular}{|c|c|c|}
\hline Date of Reading & DC Volts & DC Amps \\
\hline $1 / 10 / 95$ & +37 & 0.2 \\
\hline $8 / 15 / 96$ & +30 & 0.75 \\
\hline
\end{tabular}




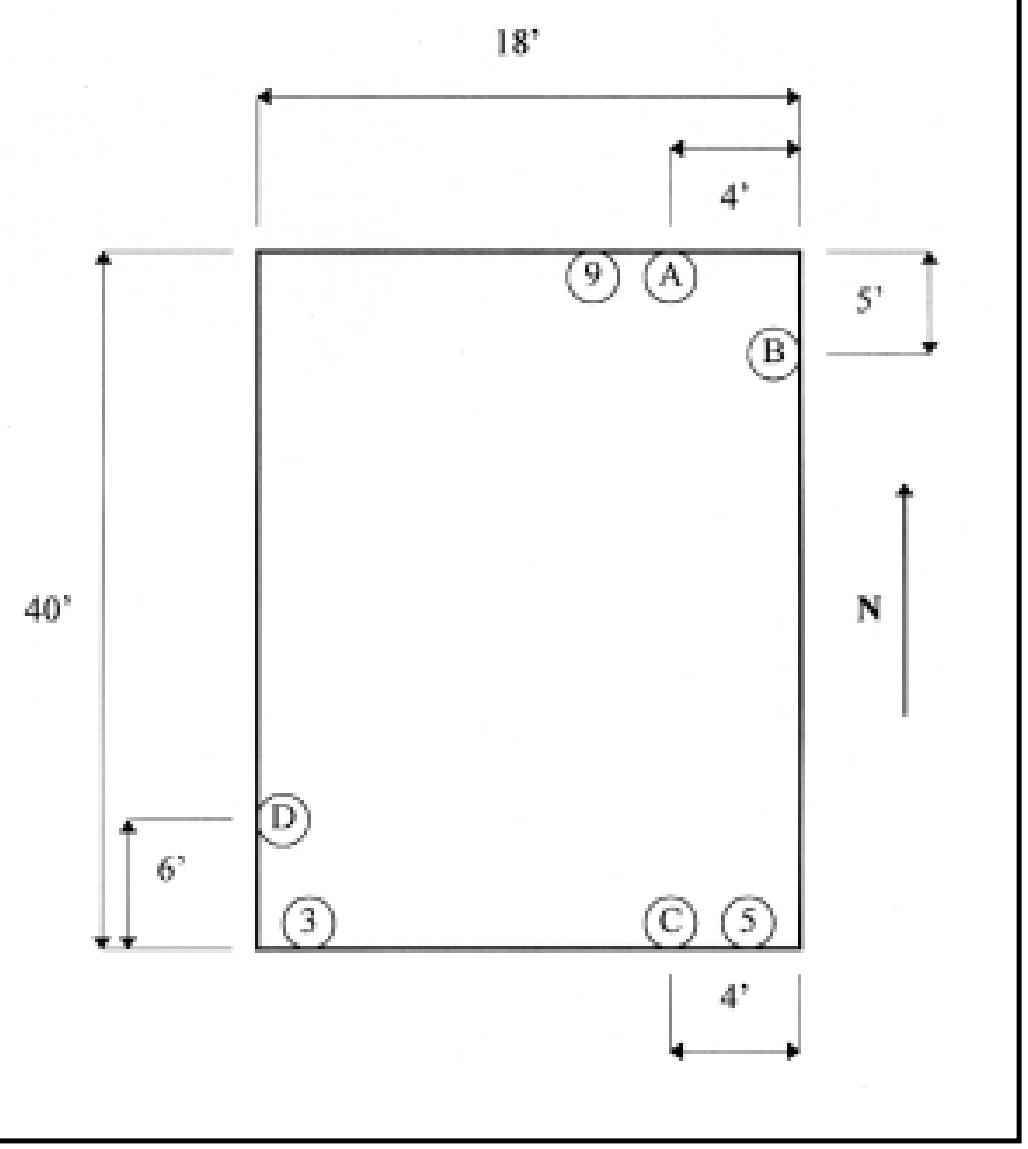

Figure 11. Locations of moisture meters and rebar specimens in basement of Building 3265.

Table 2. Concrete moisture readings in Building 3265.

\begin{tabular}{|c|c|c|c|c|}
\hline \multirow{2}{*}{ Date of Reading } & \multicolumn{4}{|c|}{ Moisture Meter Location } \\
\cline { 2 - 5 } & A & B & C & D \\
\hline $08 / 23 / 94$ & 94 & 92 & 98.3 & 97.6 \\
\hline $01 / 10 / 95$ & 44 & 43 & 68.3 & 64.3 \\
\hline $08 / 15 / 96$ & 72.5 & 72.1 & 76.3 & 76.8 \\
\hline
\end{tabular}

\section{Rebar Corrosion Potentials}

In addition to concrete moisture measurements, the corrosion of rebar specimens was investigated. Several small ( 2 -in. long) sections of 0.5-in. steel rebar were embedded in various locations in the walls of the basement at Fort J ackson. Table 3 lists the locations of these rebar specimens and Figure 11 shows the locations of three specimens. 
Table 3. Location of rebar specimens.

\begin{tabular}{|c|c|c|}
\hline Specimen \# & Location & $\begin{array}{c}\text { Wall Depth to } \\
\text { Back of Specimen }\end{array}$ \\
\hline 1 & $9 \mathrm{ft} \mathrm{N}$ of $\mathrm{SW}$ corner & $71 / 2$ in. \\
\hline 2 & 16 in. $\mathrm{N}$ of $\mathrm{SW}$ corner & $71 / 2$ in. \\
\hline 3 & 28 in. E of SW corner & $71 / 2 \mathrm{in}$. \\
\hline 4 & $91 / 2$ in. E of SW corner & $71 / 2$ in. \\
\hline 5 & 16 in. W of SE corner & $71 / 2$ in. \\
\hline 6 & $12 \mathrm{ft} \mathrm{N}$ of $\mathrm{SE}$ corner & $61 / 2 \mathrm{in.}$ \\
\hline 7 & $151 / 2 \mathrm{ft} \mathrm{N}$ of SE corner & $61 / 2$ in. \\
\hline 8 & $8 \mathrm{ft} \mathrm{S}$ of NE corner & 4 in. \\
\hline 9 & $61 / 2 \mathrm{ft} W$ of NE corner & 4 in. \\
\hline 10 & $13 \mathrm{ft} \mathrm{S}$ of NW corner & $4 \mathrm{in.}$ \\
\hline
\end{tabular}

Table 4. Specimen corrosion potentials.

\begin{tabular}{|c|c|c|c|}
\hline & \multicolumn{3}{|c|}{ Potential (Volts DC) } \\
\hline Specimen & Minimum & Maximum & Average \\
\hline 3 & -0.190 & -0.200 & -0.195 \\
\hline 5 & -0.204 & -0.224 & -0.214 \\
\hline 9 & -0.145 & -0.154 & -0.15 \\
\hline
\end{tabular}

The purpose of these specimens was to document whether any change occurs in the native corrosion potential of steel rebar that might be embedded in a concrete structure when the EOP system is operating. The corrosion potential of the specimens was tracked and compared to the average corrosion potential for reinforcing steel in concrete, which is approximately -0.2 VDC. Table 4 lists the corrosion potentials for some of the specimens. These potentials were taken at the 5-month performance check on $10 \mathrm{~J}$ anuary 1995 . The data show no significant difference in the corrosion potential from the native potential for the rebar specimens, however, these are just two time samples of a dynamic system. A larger record is needed to fully document the EOP system effect on rebar corrosion potential.

\section{Monitoring Well}

Another way to document the effectiveness of the EOP system is to track the groundwater table outside the basement wall. This is accomplished by using a monitoring well. The purpose of these measurements is simple: if the water table is above the floor of the basement and the basement remains dry, then the EOP system is fulfilling its purpose. Figure 9 shows the location of the monitoring well relative to the basement. 
Each month, Davis \& Floyd (the contractor responsible for monitoring the water table) reported the results of the water table data relative to the basement floor. Also recorded was the groundwater temperature. (Groundwater temperature was included in the standard monitoring well "package," it was not needed for this particular study.) Figure 12 shows the hydrograph from Davis \& Floyd. The results for the monitoring well began in September 1995 and ended in September 1996. Note there are several times during the recording period when the water table exceeded the basement floor level, yet because of the EOP system the basement remained dry.

Rainfall data were taken monthly at Fort J ackson to track the months when there would be a greater potential for a higher water table. These data can be correlated to the monitoring well data points, as greater rainfall would result in a higher water table. (Specifically, note the correlation between the high rainfall during March 1996 and the rise in the water table during that month.) Table 5 shows the rainfall data at Fort J ackson up to May 1996.

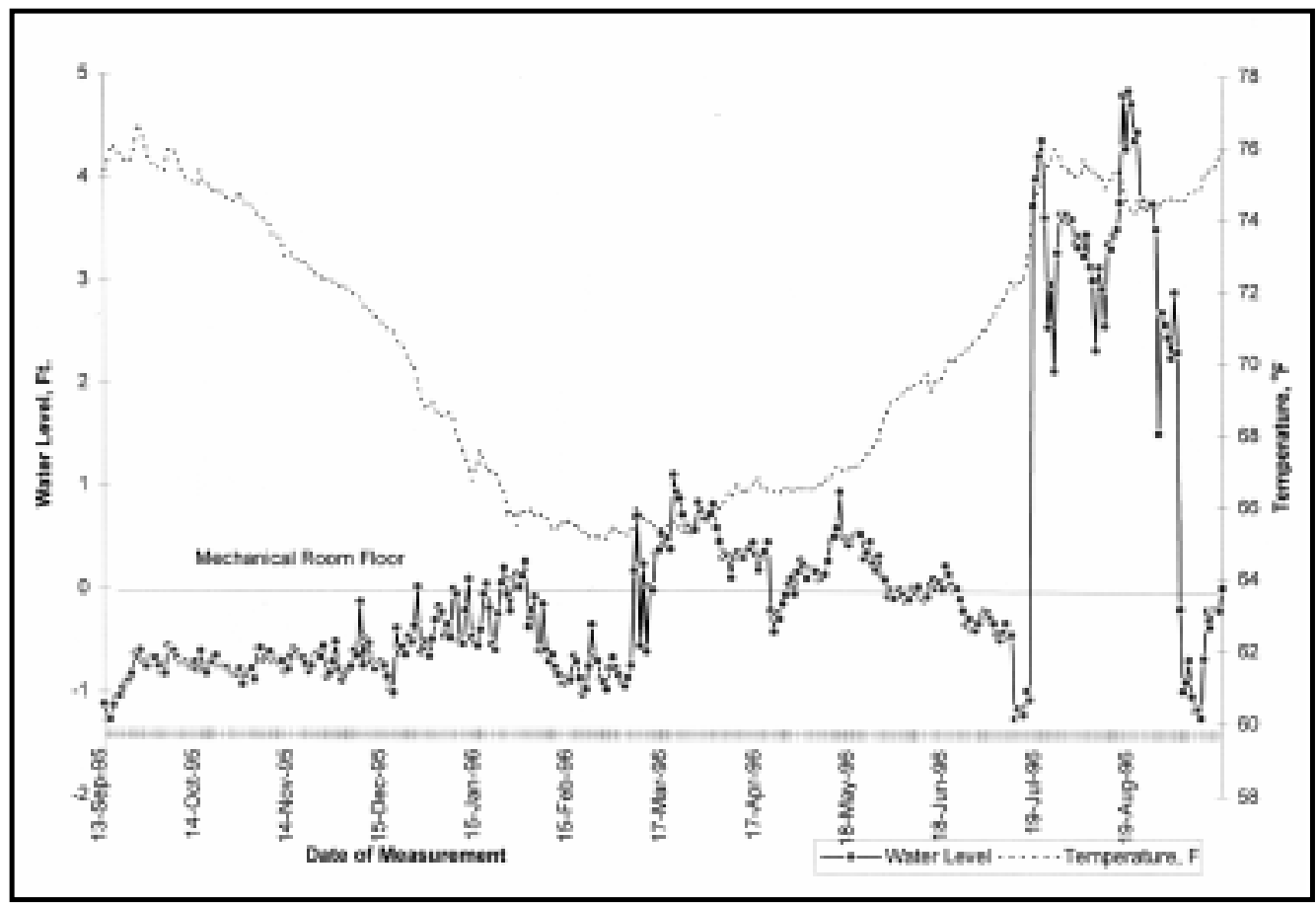

Figure 12. Hydrograph line from monitoring well Fort Jackson. 
Table 5. Average monthly precipitation data, Columbia, SC.

\begin{tabular}{|l|c|l|c|}
\hline Date & $\begin{array}{c}\text { Total } \\
\text { Precipitation (in.) }\end{array}$ & \multicolumn{1}{c|}{ Date } & $\begin{array}{c}\text { Total } \\
\text { Precipitation (in) }\end{array}$ \\
\hline August 1994 & 5.31 & July 1995 & 7.86 \\
\hline September 1994 & 3.27 & August 1995 & 6.69 \\
\hline October 1994 & 4.74 & September 1995 & 5.51 \\
\hline November 1994 & 3.08 & October 1995 & 3.61 \\
\hline December 1994 & 5.83 & November 1995 & 2.89 \\
\hline January 1995 & 4.49 & December 1995 & 2.19 \\
\hline February 1995 & 6.70 & January 1996 & 2.90 \\
\hline March 1995 & 1.70 & February 1996 & 1.16 \\
\hline April 1995 & 0.98 & March 1996 & 6.52 \\
\hline May 1995 & 1.69 & April 1996 & 2.38 \\
\hline June 1995 & 10.74 & May 1996 & 2.68 \\
\hline
\end{tabular}

\section{McAlester AAP}

\section{Installation}

On $23 \mathrm{~J}$ uly 1996, installation began at McAlester. Figure 13 shows a layout of the basement in Building 5. During a walk-through of the building the previous day, standing water was seen in several areas of the basement. The locations of water infiltration were determined. These were in rooms A, B, and C. No intrusion was noted in the boiler room and under the stairwell, so the EOP system was not installed in these locations. In the unexcavated areas of the structure (crawl spaces), labeled "I" and " $K$ " in the figure, it was noted that water had entered through a horizontal cold joint approximately $2 \mathrm{ft}$ from the top of the foundation walls. To prevent further water intrusion into these unexcavated areas, the cold joint was chiseled out and replaced with caulk.

The Drytronic technicians chiseled out an area of the concrete along the floorwall juncture in the Industrial Hygiene Office (designated as "A" in the figure) where a horizontal crack was discovered. This area was patched over with new concrete. Concrete and soil resistivity tests were performed and the anode and cathode locations determined.

\footnotetext{
* A "cold joint" results when fresh concrete has been poured over set concrete.
} 


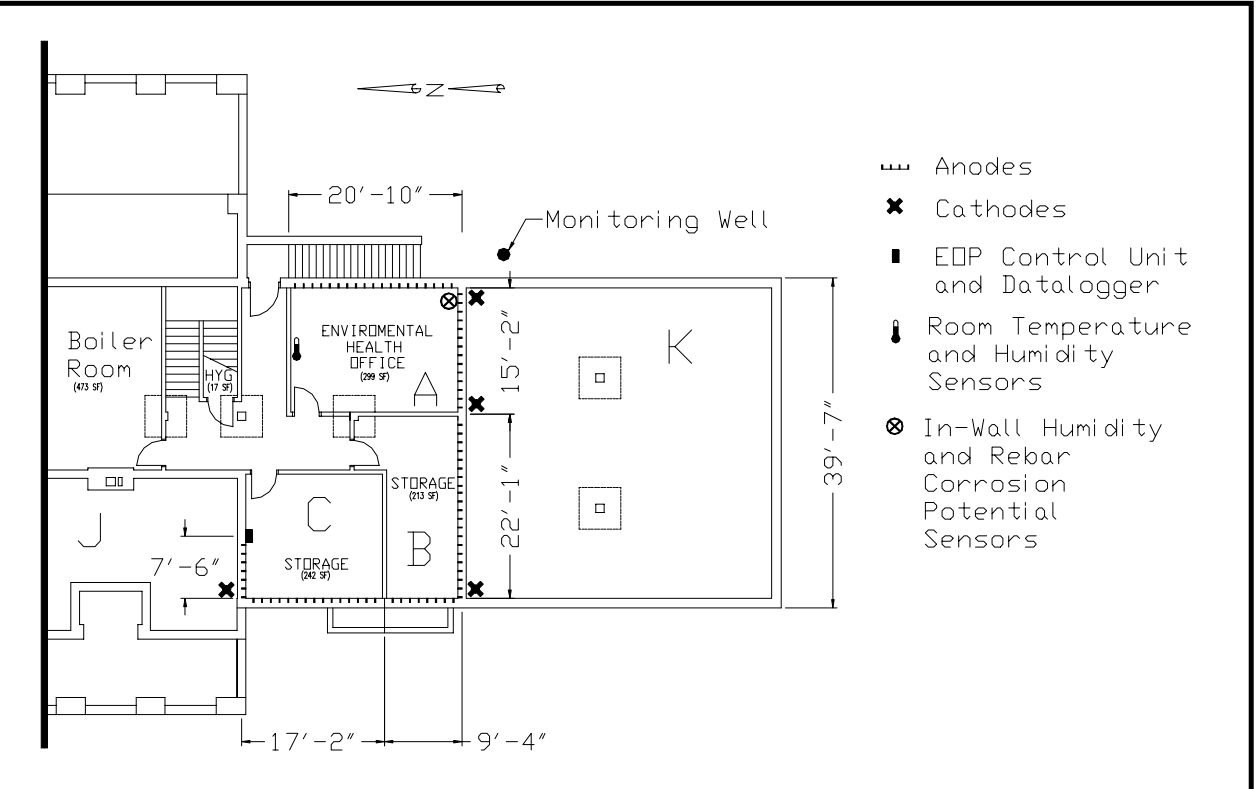

Figure 13. Basement of Building 5 at McAlester AAP.

Technicians then fastened a plastic wire mold onto the inside of the exterior concrete walls of the rooms where the EOP system was to be installed. These rooms are designated on Figure 13 as " $A$ " (Industrial Hygiene Office), " $B$ " (Medical Supply Storage Room), and "C" (Electrical Room). This wire mold was mounted 5 in. above the floor and conceals the anodes and system wiring. $J$ unction boxes were placed every $15 \mathrm{ft}$ along the wire mold. Holes were then drilled through this wire mold and into the concrete walls. These holes, to accommodate the anodes, were drilled 6 in. into the concrete walls, 5 in. above the floor and $11 \mathrm{in}$. on center. The total number of anodes is 95 and the number of anodes for each wall is: $20,15,24,9,19$, and 8 , respectively, starting with the east wall in room $A$, and moving clockwise around the basement. Rubbergraphite anodes were coated with a graphite-mortar mixture and inserted into the holes. The anodes were wired in segments of about 20 anodes. The segments were then connected in a parallel and redundant manner (connected at both ends) to the power supply. All wiring was enclosed in the wire mold.

Copper-clad steel grounding rods (cathodes), $8 \mathrm{ft}$ long, were driven into the ground in selected areas. This project required five cathodes and they were placed as indicated in Figure 13. Wiring from the cathodes was installed and placed in the wire mold. To differentiate the wires, blue wire connected the anodes and black the cathodes. The covering for the wire mold was then secured in place.

Drytronic technicians drilled holes at several places in the basement walls for sensors: holes were drilled perpendicular to the wall surface in three different 
locations to accommodate 6-in. Iong rebar specimens; a horizontal groove measuring $16 \mathrm{in}$. long by $1.5 \mathrm{in}$. deep was chiseled $8 \mathrm{in}$. above the floor into the south wall of the Industrial Hygiene Office to hold a long steel rebar specimen; a hole was drilled at a 45 degree angle downward into the wall behind this groove for a corrosion reference cell; and finally a hole was drilled in the south wall near the southeast corner of the Industrial Hygiene Office to accommodate a temperature and humidity sensor. The rebar specimens were used by CERL to monitor rebar corrosion potential and the temperature and humidity probe was used to monitor moisture in the concrete wall. Finally, the EOP Control Unit was mounted on the north wall of the electrical room (labeled " $C$ " in Figure 13). The relative humidity in the Industrial Hygiene Office was 70 percent at this time. The installation portion of this project was completed on $31 \mathrm{~J}$ uly 1996.

The EOP waveform was recorded by an oscilloscope on several occasions. The oscilloscope provides a real-time picture of the waveform and shows the maximum, average, and minimum voltage values and the point at which the voltage goes to zero. Figure 14 shows a waveform taken from the EOP unit at McAlester AAP, November 1996. The normal operating voltage range, peak to peak, is $\approx 60$ Volts DC (VDC). The positive voltage peak was $\approx 30$ VDC. During the positive pulse, the water is forced in the direction of the cathode or to the exterior surface of the concrete.

\section{Monitoring System}

Many of the same parameters that were recorded at Fort J ackson are being recorded at McAlester. The corrosion potential is taken using a 13-in. Iong piece of 0.5 -in. steel rebar that was grouted into the wall along with a $\mathrm{Ag} / \mathrm{AgCl}$ reference cell. The cell was installed so as to be behind the rebar, and separated from it by about 2 in. of concrete. The humidity of the concrete is sampled, but not with the same technique used at Fort Jackson. A small cavity (approximately 6-in. long) was made in the concrete wall for the insertion of a 4in. Iong dual humidity/temperature probe. After the probe was inserted into the cavity, the cavity was sealed off from the room air. Since the cavity is sealed, this probe monitors the temperature and humidity of the cavity, giving an indication of the progress of the EOP system as it operates. The humidity of the cavity should be proportional to the moisture content of the concrete. 


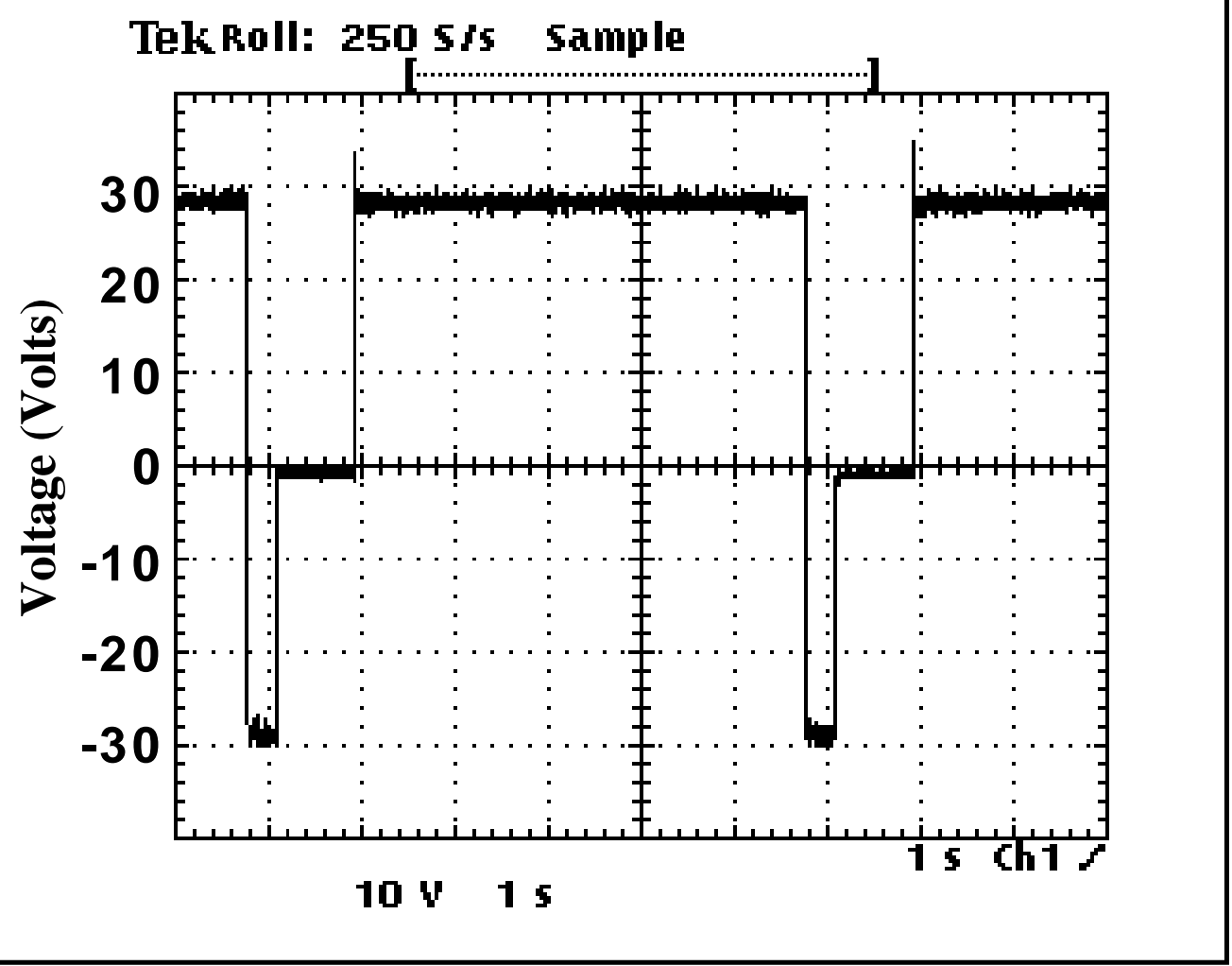

Figure 14. EOP unit output waveform recorded at McAlester AAP, November 1996.

Ambient room humidity and temperature sensors are monitoring the Industrial Hygiene Office. A well was installed to monitor the level of the water table outside the basement. In addition to these sensors and probes, the electrical power consumption of the EOP system is monitored to determine the power output of the power supply and the cost of operation. Most of these monitoring devices are fed into a datalogger that is installed on site and is remotely accessible via modem. The data is collected and stored in the datalogger until downloaded to a computer.

The parameters being remotely monitored in Building 5 are:

1. The EOP Control Unit AC input voltage

2. The EOP Control Unit AC input current

3. The room temperature of the Industrial Hygiene Office (IHO)

4. The relative humidity of the IHO

5. The temperature within the $6 \mathrm{in}$. cavity of the east wall of the $\mathrm{IHO}$

6. The relative humidity within the 6-in. cavity of the east wall of the IHO

7. The level of the water table directly outside of the IHO. 
The EOP control Unit DC output power is being computed from the AC input power and the known power consumption of the unit's control el ectronics.

Rebar potentials are being sampled about every 4 months. Unfortunately they could not be sampled remotely; they must be measured on site.

The daily rainfall, average outdoor temperature, and average outdoor relative humidity at McAlester are obtained from the Oklahoma Climatological Survey (Data is downloaded monthly from their INTERNET site). Sample data are included in the Appendix to this report.

Figure 15 shows some of the recorded data, and highlights the power consumption of the EOP system in relation to the relative humidity in the wall, as measured by the wall probe. Figure 15 shows that, initially, as the power consumption drops (as a result of the decrease in current as the water is driven out), the concrete humidity drops as well. This shows that the EOP system is decreasing the moisture content in the concrete and is decreasing its power requirements, both excellent indicators that the system is working properly. Figure 16 shows the water table with respect to the basement floor. (Figure 16 gives the same information for McAlester that Figure 12 gives for Fort J ackson.) Unlike the conditions recorded at Fort J ackson the water table at M cAlester AAP does not rise above the basement floor. Therefore the water intrusion problem at McAlester is due entirely to periodic saturation of the nearby soil. This conclusion is further supported by the building's occupants, who stated that the water came in following rainstorms. 


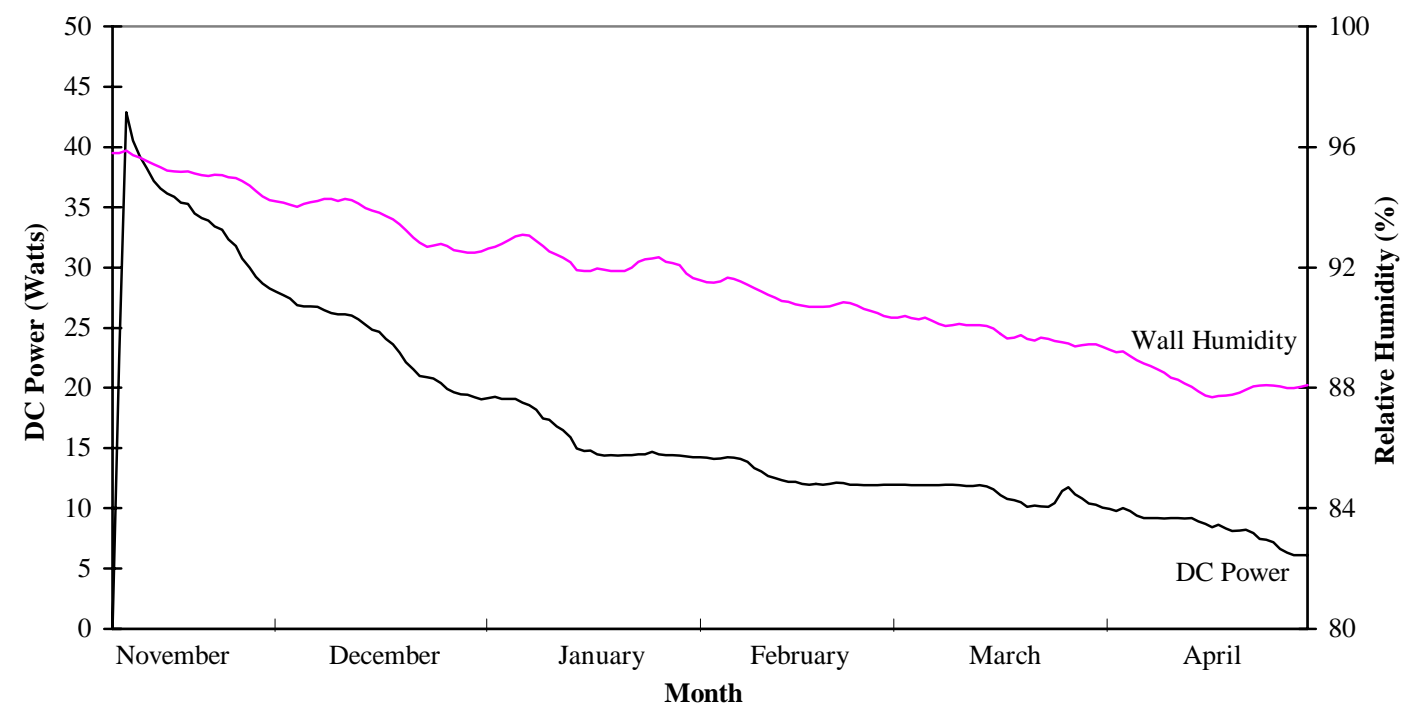

Figure 15. Power consumption of EOP system in relation to relative humidity in the wall.

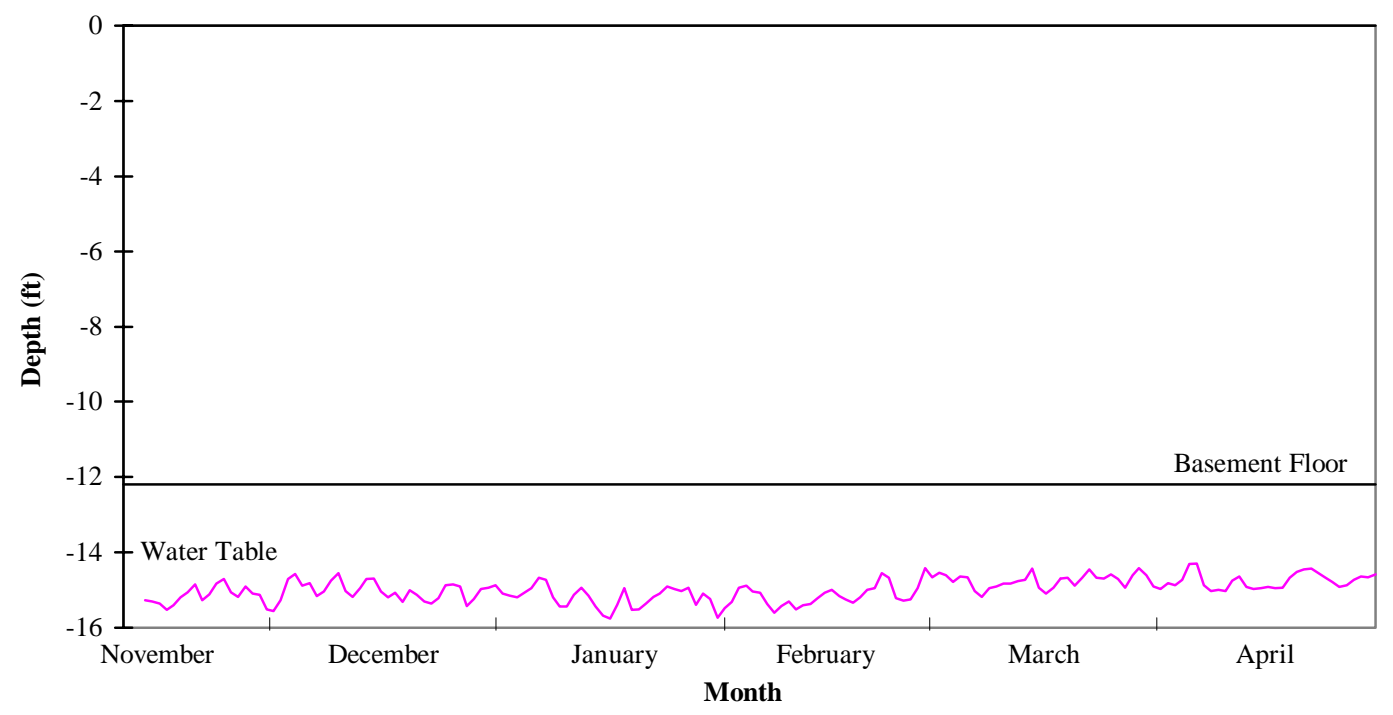

Figure 16. Water table with respect to the basement floor for McAlester AAP. 


\section{Cost/Benefit Analysis}

\section{Background}

EOP technology should be used selectively. A properly designed and constructed building foundation with appropriate damp-proofing will correct most water problems inherent in the traditional designs of many foundation systems. However, severe problems in existing basements may require a more serious approach to mitigate moisture damage. In these selective problem areas, the common approach to mitigation is to excavate to expose the wall area and the base of the foundation, and then to replace the damp-proofing on the wall surface and install a drain tile system around the building or affected area. This is a costly endeavor. Furthermore, most contractors severely limit their warrantee against future seepage in areas with high water tables.

In buildings with daily occupancies and mature landscaping, retrofitting (by "trenching and draining") a foundation is not easy. (In the case of McAlester, 30 percent of the wall faced an exterior crawl space. Mechanical equipment could not perform in so tight a space, so hand digging would have been required.) Any interior application that can mitigate water-related problems will save the cost of excavation. Further, if the alternative can mitigate corrosion damage to mechanical equipment along with humidity and mold problems, it will yield benefits beyond the initial cost savings.

How to best estimate the initial cost savings for purposes of decisionmaking must be based on experience and standard construction industry reference costestimating guides. The comparison of the standard waterproofing technology to EOP technology is based on field experience at Fort J ackson and at McAlester AAP. Figures 17 and 18 show the results of EOP application at F ort J ackson and McAlester AAP. 


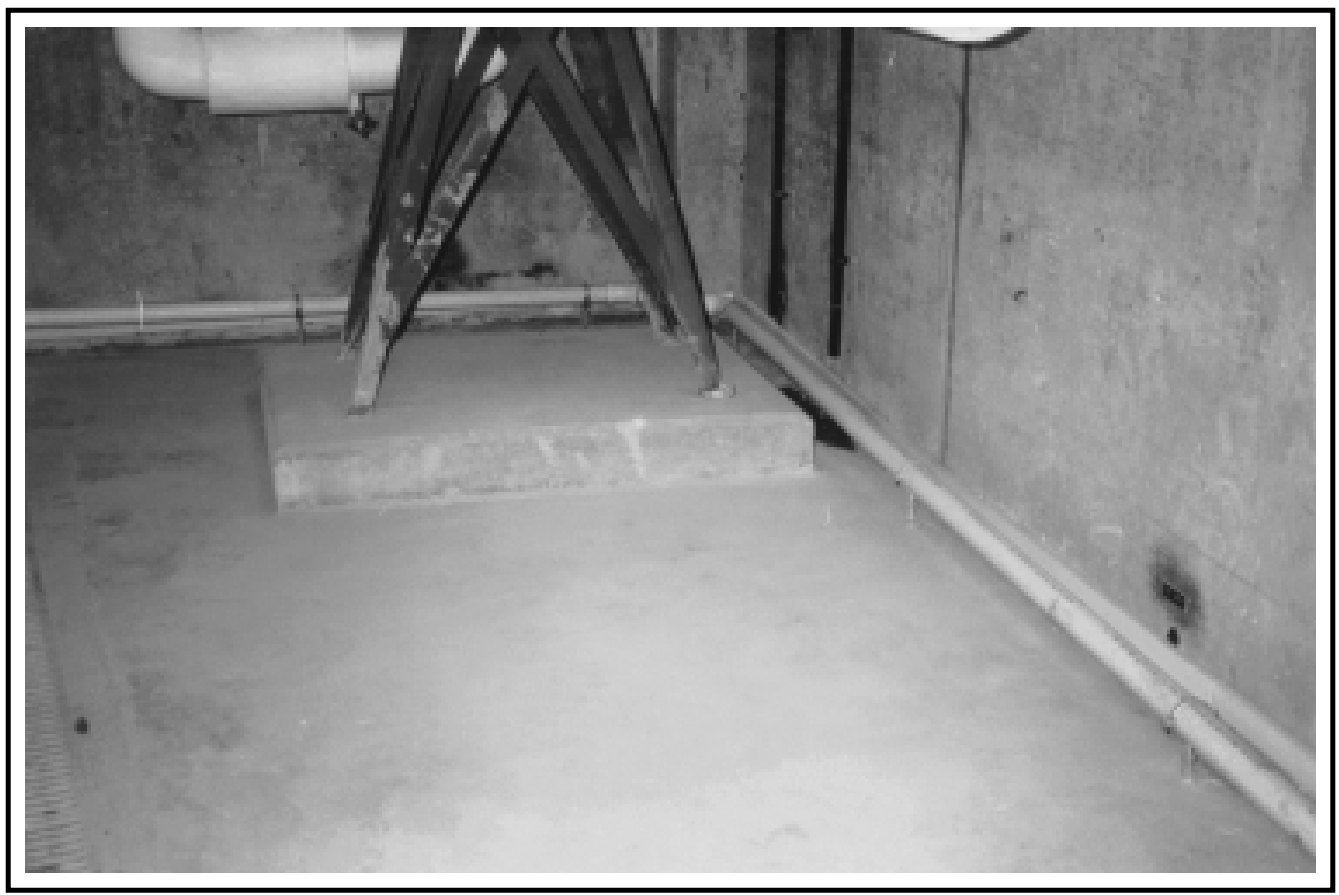

Figure 17. Dry floor in basement of building 3265, Fort Jackson, following EOP application.

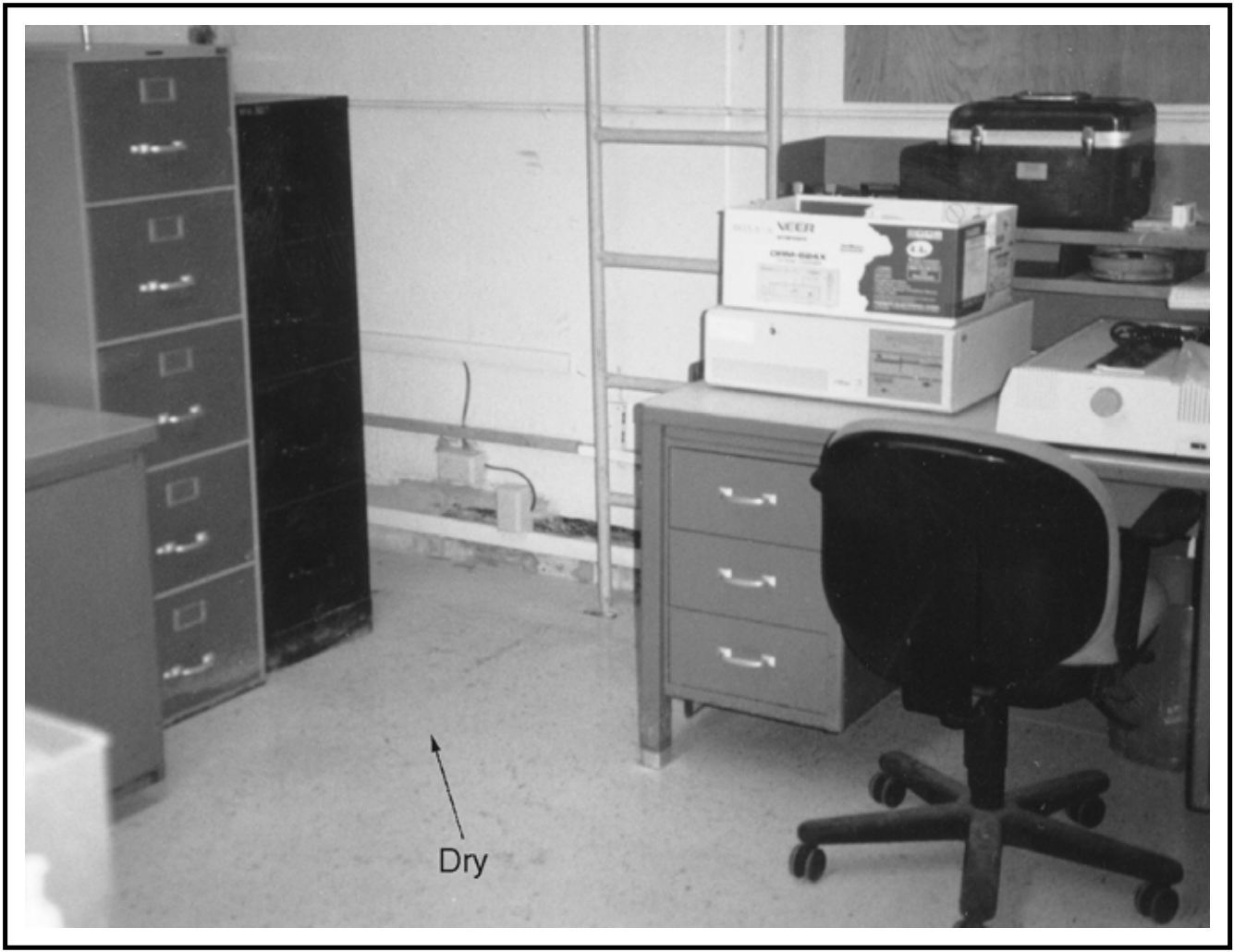

Figure 18. Dry floor in basement of Building 5, McAlester AAP, following EOP application. 


\section{Estimating the Cost of the Standard Approach}

Since many installations have serious seepage problems that do not respond to simple mitigation problems, i.e., caulking, grouting, and interior damp-proofing paint, the next (and more difficult solution) is to prepare the site for excavation and tiling for drains (many older buildings were constructed without drains at all). References from Means Cost Estimating Guides, Walker Estimating Guide, and the National Construction Estimator Handbook can be used to estimate material costs. All of these guides give costs that can be adjusted for regional applications. The focus of this estimate is a standard basement about 8-ft deep with a concrete exterior.

The standard estimate is drawn from construction cost guides, which is then compared to the results of the Army test sites. The following sections note adjustments and explain cost variances.

\section{Standard Approach Estimate}

The following is a breakdown of the cost for mitigation without using the EOP system:

1. Site Dewatering: Where there is serious seepage, a dewatering system must be installed before excavation. This consists of well points, drain headers, and rented pump equipment (usually for 30 days or more).

2. Wood Shoring: Assuming the structure has an 8-ft deep foundation wall with wet soil, at least 25 percent will have to be wood shored (maybe more to provide access and protect workers).

3. Excavation and Backfill: Generally, in a constructed facility with underground utilities and limited mechanical access, one will have to handexcavate adjacent to the walls and to the utility lines. Assuming the building will still be occupied during this process, some disruption of normal services will likely occur. National Construction Cost Estimator gives \$117 to \$144/cu 
$\mathrm{yd}^{*}$ as a base range, depending on soil conditions. One can use an average estimated at $\$ 125 / \mathrm{cu}$ yd.

4. Install Drain Tile: Assuming a retrofit common action of plastic perforated drain tile in a gravel bed at the edge of the footing, one can assume a range from \$4.19 to \$4.31/linear foot (If) including O\&P (1993 Means Cost Estimating Guide). Note that steel, clay and concrete pipe are reasonable, but more expensive alternates.

5. Damp-proofing: Common practice is to apply a coating to the exterior surface of the exposed foundation wall. Alternate approaches based on soil conditions and water content might be a fluid elastomeric at $1.61 / \mathrm{sq} \mathrm{ft}$, a bituminous coating at $\$ 0.69 / \mathrm{sq} \mathrm{ft}$, or in more serious leakage situations, an EDPM membrane applied to the wall at $\$ 1.44$ to $\$ 1.96 / \mathrm{sq} \mathrm{ft}$. For estimating, $\$ 1.00 /$ sq ft will be used.

6. Backfilling: In the process of excavation, one assumes hand work and placing the soil adjacent to the trench. For backfilling, one can assume mechanical backfilling with some tamping of the soil $(\$ 1.10 / \mathrm{f}$ in Means Building Construction Cost Data).

7. Landscaping Restoration: Most areas adjacent to existing buildings will have mature grass or greenery that will have been disrupted by the excavation process. Restoration consists of reseeding, fertilizing, and replanting shrubs for the building perimeter.

Table 6 gives the breakdown of the costs for each facet listed above, including the approximation of the cost per linear foot (If) of the exterior foundation wall. This assumes a contract for the whole building and standard depth of $8 \mathrm{ft}$ with average, but wet soil conditions.

\section{Estimating the Cost of EOP Technology}

The original contracts to the EOP installer were analyzed and adjustments were made to the contract prices to reflect generic installations (i.e., travel, monitoring wells, report requirements, and certain extra experimental requirements have been eliminated from the base costs).

\footnotetext{
* $1 \mathrm{cu} \mathrm{yd}=0.765 \mathrm{~m}^{3} ; 1 \mathrm{sq} \mathrm{ft}=0.093 \mathrm{~m}^{2}$.
} 
The prices in Table 7 reflect the costs of the EOP system and labor only. Next, the price of the EOP system based on installed costs and linear foot of wall must be calculated. As for installation, both sites required some degree of interior access to the basement level, but neither excavation nor damp-proofing were required. Installation of the probes is generally based on a 18-in. spacing and about 4 in. to 8 in. from the floor level. The price includes the EOP Control Unit, anodes, ground rods, and all the wiring and labor for installation (Table 8).

The installer, Drytronic, Inc., estimates life cycle of the equipment and the pulsing technology system to be greater than 10 years. Therefore, one could assume a normal cycle with almost zero maintenance for that period of time. The system does consume energy in the equivalent of a $60 \mathrm{~W}$ light bulb left on all the time. At $\$ 0.06 / \mathrm{kWh}$ national electrical cost, this cost is minimal and is disregarded in this study. In most basement seepage conditions, one option often tried is a sump pump (with a 10 year life) and associated piping. The resulting energy costs would be a "wash" over time. Keep in mind that one is dealing with extreme dampness conditions that probably have had many interim repairs, from caulking and grouting to exterior impregnation of the soil with cement binders and polymers to stop water migration. Obviously the life cycle of these "fixes" was very short, or the engineer would not be considering trenching or EOP technology.

Table 6. Standard approach cost estimate.

\begin{tabular}{|l|c|}
\hline Action & Cost per If \\
\hline Site dewatering & $\$ 67.53$ \\
\hline Wood shoring & $\$ 10.60$ \\
\hline Excavation and backfill & $\$ 222.00$ \\
\hline Drain tile installation & $\$ 4.20$ \\
\hline Damp-proofing & $\$ 8.00$ \\
\hline Backfilling & $\$ 1.10$ \\
\hline Landscaping restoration & $\$ 1.86$ \\
\hline Total & $\$ 315.20$ \\
\hline
\end{tabular}

Table 7. Costs of EOP technology installation.

\begin{tabular}{|l|c|}
\hline Location & Cost \\
\hline McAlester AAP & $\$ 18,071$ \\
\hline Fort Jackson & $\$ 20,729$ \\
\hline
\end{tabular}

Table 8. Calculation of EOP System Based on Installed Costs and If of Wall.

\begin{tabular}{|l|c|c|}
\hline Location & Linear Feet Installed & Cost per Linear Foot \\
\hline McAlester AAP & 95 & $\$ 190.22$ \\
\hline
\end{tabular}




\begin{tabular}{|l|c|c|}
\hline Fort Jackson & 113 & $\$ 186.75$ \\
\hline Average Cost of EOP Installation for Both Sites & $\$ 188.49$ \\
\hline
\end{tabular}

\section{Payback for EOP Technology}

The percent savings based on capital costs is basically a comparison between the cost of trenching, damp-proofing, backfilling, and installed EOP technology. The comparison is:

$$
\% \text { first cost saved }=100 \times\left(1-\frac{\text { EOP per If }}{\text { Trench \& Drain per If }}\right)=100 \times\left(1-\frac{\$ 188.49}{\$ 315.20}\right)=40 \%
$$

Payback is based on a calculation of time taken to recoup the original investment. One can determine how long it would take to save investment moneys for EOP over a comparable spending for a trench and drain system. This is called Payback U pon Price Comparison $\left(\mathrm{P}_{\mathrm{PC}}\right)$ :

$$
\mathrm{P}_{\mathrm{PC}}=\frac{1}{\frac{\text { Trench \& Drain per If - EOP per If }}{\text { EOP per If }}}=\frac{\frac{1}{\$ 126.71}}{\frac{\$ 188.49}{0.67}}=1.49 \text { years }
$$

This is an internal return on investment, based solely on initial costs. It does not represent the savings over time.

One might also consider some intangible (certainly difficult to quantify) benefits:

1. There is minimal disruption of the building activity during the drying out process, e.g., no digging, minor noise, and a small amount of waste.

2. Illnesses caused by allergies or other sensitivities will be reduced, thereby increasing health and productivity of the building occupants.

In summary, both the economic benefits based on conservative estimates from field data, and the intangible benefits, point to a very positive return-oninvestment for EOP technology. 


\section{Conclusions and Recommendations}

Based on the results of demonstrations and validations, this study concludes that the application of EOP technology for control of water seepage in concrete basement structures is an acceptable alternative to conventional trenching and tiling.

The EOP technology installed in the mechanical room of Building 3265, Fort J ackson, SC successfully prevented water seepage and reduced the relative humidity of the concrete to 70 percent. The cost of installation has been determined to be 40 percent lower than the cost of the conventional trench and drain approach. The operating or energy cost of the EOP system is negligible equival ent to the expenditure of burning a 60W light bulb.

It is recommended that the EOP technology be transferred for Army-wide implementation as a cost effective alternative to the "trench/drain" approach for control of moisture in concrete basement structures. Technology transfer should be facilitated through the publication of a FEAP user guide and ad flyer. Draft EOP specifications should be prepared and submitted for incorporation into the Corps of Engineers Guide Specifications. 


\section{References}

Hamill, W.H., R.R. Williams, and C. MacKay, Principles of Physical Chemistry, 2d ed. (PrenticeHall, Inc., Englewood Cliffs, NJ , 1966).

Glasstone, S., Textbook of Physical Chemistry, 2d ed. (D. Van Nostrand Company, Inc., Princeton, NJ , 1946).

Tikhomolova, K.P., Electro-Osmosis (Ellis Horwood Limited, Chichester, West Sussex, England, 1993).

Means Cost Estimating Guides (R.S. Means Company, Inc., Construction Publishers and Consultants, 100 Construction Plaza, P.O. Box 800, Kingston, MA 12364-0800).

Walker Estimating Guide (Frank R. Walker Company, Publishers, 5030 N. Harlem Ave., Chicago, IL 60656).

National Construction Estimator Handbook (Craftsman Book Company, 6058 Corte del Cedro, PO Box 6500, Carlsbad, CA 92018-6500). 


\section{Appendix: Data Logged From Building 5, McAlester AAP, OK}

The following table contains data recorded by the logger at Building 5, McAlester AAP, OK. The data most important to tracking the progress of the EOP system are those labeled "Watts DC," "Wall RH," "Well," and "Rainfall." These report the DC output power from the EOP power supply, the relative humidity within a wall cavity, the water table depth, and rainfall, respectively.

\begin{tabular}{|c|c|c|c|c|c|c|c|c|c|c|c|}
\hline Date & $\begin{array}{c}\text { AC } \\
\text { Volts }\end{array}$ & $\begin{array}{c}\mathrm{AC} \\
\text { Amps }\end{array}$ & $\begin{array}{c}\text { DC Watts } \\
\text { (Computed) }\end{array}$ & $\begin{array}{c}\text { Rom } \\
\text { Temp }\end{array}$ & $\begin{array}{c}\text { Room } \\
\text { RH }\end{array}$ & $\begin{array}{l}\text { Wall } \\
\text { Temp }\end{array}$ & $\begin{array}{c}\text { Wall } \\
\text { RH }\end{array}$ & Well & Rainfall & $\begin{array}{c}\text { Outdoor } \\
\text { Temp } \\
\text { (Average) }\end{array}$ & $\begin{array}{c}\text { Outdoor RH } \\
\text { (Average) }\end{array}$ \\
\hline $11 / 6 / 96$ & 209.67 & 0.00 & $*$ & 74.45 & 56.89 & 71.51 & 95.80 & * & 1.97 & 66.10 & 84.00 \\
\hline $11 / 7 / 96$ & 208.92 & 0.15 & 22.56 & 73.70 & 45.05 & 71.41 & 95.79 & * & 1.08 & 50.30 & 71.00 \\
\hline $11 / 8 / 96$ & 209.18 & 0.25 & 42.85 & 71.34 & 37.61 & 71.26 & 95.88 & * & 0.00 & 45.20 & 58.00 \\
\hline $11 / 9 / 96$ & 209.27 & 0.24 & 40.54 & 69.83 & 44.27 & 71.01 & 95.74 & -15.26 & 0.00 & 50.10 & 59.00 \\
\hline $11 / 10 / 96$ & 209.47 & 0.23 & 39.17 & 69.15 & 40.46 & 70.87 & 95.65 & -15.31 & 0.00 & 46.80 & 52.00 \\
\hline $11 / 11 / 96$ & 209.61 & 0.23 & 38.26 & 68.28 & 41.83 & 70.59 & 95.55 & -15.36 & 0.00 & 49.30 & 62.00 \\
\hline $11 / 12 / 96$ & 208.98 & 0.22 & 37.17 & 69.03 & 42.77 & 70.46 & 95.43 & -15.54 & 0.00 & 45.40 & 74.00 \\
\hline $11 / 13 / 96$ & 209.07 & 0.22 & 36.54 & 69.38 & 49.32 & 70.38 & 95.32 & -15.40 & 0.00 & 48.20 & 89.00 \\
\hline $11 / 14 / 96$ & 209.04 & 0.22 & 36.15 & 70.05 & 56.58 & 70.46 & 95.21 & -15.20 & 0.00 & 54.20 & 88.00 \\
\hline $11 / 15 / 96$ & 209.56 & 0.22 & 35.86 & 70.04 & 60.33 & 70.53 & 95.19 & -15.06 & 0.05 & 58.50 & 77.00 \\
\hline $11 / 16 / 96$ & 209.50 & 0.21 & 35.36 & 70.94 & 63.58 & 70.65 & 95.18 & -14.86 & 1.41 & 62.70 & 86.00 \\
\hline $11 / 17 / 96$ & 209.44 & 0.21 & 35.24 & 70.29 & 56.43 & 70.63 & 95.19 & -15.27 & 0.00 & 41.50 & 77.00 \\
\hline $11 / 18 / 96$ & 209.11 & 0.21 & 34.47 & 69.81 & 49.67 & 70.42 & 95.13 & -15.12 & 0.00 & 44.70 & 79.00 \\
\hline $11 / 19 / 96$ & 209.15 & 0.21 & 34.10 & 70.89 & 52.69 & 70.51 & 95.06 & -14.83 & 0.00 & 55.30 & 90.00 \\
\hline $11 / 20 / 96$ & 209.39 & 0.21 & 33.88 & 72.40 & 58.83 & 70.81 & 95.04 & -14.71 & 0.00 & 62.50 & 89.00 \\
\hline $11 / 21 / 96$ & 209.30 & 0.21 & 33.42 & 72.22 & 50.83 & 70.97 & 95.09 & -15.06 & 0.00 & 51.30 & 81.00 \\
\hline $11 / 22 / 96$ & 209.75 & 0.20 & 33.12 & 70.14 & 47.37 & 70.75 & 95.05 & -15.19 & 0.00 & 50.10 & 69.00 \\
\hline $11 / 23 / 96$ & 209.51 & 0.20 & 32.30 & 70.22 & 51.97 & 70.64 & 94.99 & -14.91 & 0.94 & 56.60 & 80.00 \\
\hline $11 / 24 / 96$ & 209.45 & 0.20 & 31.77 & 68.58 & 45.78 & 70.38 & 94.97 & -15.09 & 1.72 & 33.10 & 92.00 \\
\hline $11 / 25 / 96$ & 209.16 & 0.19 & 30.74 & 65.21 & 43.79 & 69.61 & 94.86 & -15.13 & 0.00 & 29.40 & 92.00 \\
\hline $11 / 26 / 96$ & 208.95 & 0.19 & 30.00 & 63.80 & 44.76 & 68.82 & 94.72 & -15.52 & 0.07 & 30.20 & 87.00 \\
\hline $11 / 27 / 96$ & 208.94 & 0.19 & 29.20 & 62.99 & 44.39 & 68.19 & 94.54 & -15.56 & 0.25 & 30.70 & 88.00 \\
\hline $11 / 28 / 96$ & 208.37 & 0.18 & 28.65 & 63.61 & 44.55 & 68.00 & 94.36 & -15.27 & 0.41 & 36.20 & 75.00 \\
\hline $11 / 29 / 96$ & 209.34 & 0.18 & 28.24 & 64.88 & 51.89 & 67.96 & 94.24 & -14.70 & 1.52 & 44.80 & 92.00 \\
\hline $11 / 30 / 96$ & 209.51 & 0.18 & 27.95 & 66.46 & 54.48 & 68.08 & 94.19 & -14.57 & 0.04 & 48.50 & 92.00 \\
\hline $12 / 1 / 96$ & 209.46 & 0.18 & 27.68 & 66.68 & 46.06 & 68.15 & 94.14 & -14.89 & 0.00 & 41.00 & 63.00 \\
\hline $12 / 2 / 96$ & 209.55 & 0.18 & 27.44 & 67.10 & 43.65 & 68.19 & 94.09 & -14.82 & 0.00 & 48.10 & 58.00 \\
\hline $12 / 3 / 96$ & 209.04 & 0.17 & 26.90 & 75.52 & 31.81 & 68.77 & 94.02 & -15.16 & 0.00 & 42.30 & 64.00 \\
\hline $12 / 4 / 96$ & 209.14 & 0.17 & 26.78 & 81.23 & 23.94 & 69.95 & 94.11 & -15.05 & 0.01 & 42.70 & 72.00 \\
\hline $12 / 5 / 96$ & 209.28 & 0.17 & 26.79 & 83.52 & 24.36 & 70.99 & 94.18 & -14.74 & 0.10 & 46.50 & 66.00 \\
\hline
\end{tabular}




\begin{tabular}{|c|c|c|c|c|c|c|c|c|c|c|c|}
\hline Date & $\begin{array}{c}\text { AC } \\
\text { Volts }\end{array}$ & $\begin{array}{c}\text { AC } \\
\text { Amps }\end{array}$ & $\begin{array}{l}\text { DC Watts } \\
\text { (Computed) }\end{array}$ & $\begin{array}{l}\text { Rom } \\
\text { Temp }\end{array}$ & $\begin{array}{c}\text { Room } \\
\text { RH }\end{array}$ & $\begin{array}{l}\text { Wall } \\
\text { Temp }\end{array}$ & $\begin{array}{c}\text { Wall } \\
\text { RH }\end{array}$ & Well & Rainfall & $\begin{array}{l}\text { Outdoor } \\
\text { Temp } \\
\text { (Average) } \\
\end{array}$ & $\begin{array}{c}\text { Outdoor RH } \\
\text { (Average) }\end{array}$ \\
\hline $12 / 6 / 96$ & 209.64 & 0.17 & 26.73 & 84.06 & 24.01 & 71.85 & 94.21 & -14.56 & 0.00 & 54.60 & 50.00 \\
\hline $12 / 7 / 96$ & 209.61 & 0.17 & 26.45 & 84.75 & 21.72 & 72.52 & 94.29 & -15.03 & 0.00 & 47.10 & 58.00 \\
\hline $12 / 8 / 96$ & 209.51 & 0.17 & 26.25 & 84.82 & 20.43 & 72.93 & 94.27 & -15.18 & 0.00 & 45.00 & 57.00 \\
\hline $12 / 9 / 96$ & 209.22 & 0.17 & 26.11 & 87.51 & 22.05 & 73.53 & 94.21 & -14.96 & 0.00 & 56.90 & 51.00 \\
\hline $12 / 10 / 96$ & 209.32 & 0.17 & 26.12 & 86.62 & 32.81 & 74.15 & 94.27 & -14.72 & 0.00 & 64.70 & 71.00 \\
\hline $12 / 11 / 96$ & 209.40 & 0.17 & 25.98 & 79.20 & 39.96 & 73.79 & 94.23 & -14.70 & 0.00 & 61.10 & 69.00 \\
\hline $12 / 12 / 96$ & 209.28 & 0.17 & 25.66 & 76.63 & 34.11 & 73.19 & 94.12 & -15.04 & 0.00 & 49.10 & 80.00 \\
\hline $12 / 13 / 96$ & 209.76 & 0.17 & 25.25 & 74.04 & 38.79 & 72.61 & 93.97 & -15.20 & 0.00 & 53.60 & 79.00 \\
\hline $12 / 14 / 96$ & 209.64 & 0.16 & 24.83 & 73.69 & 45.72 & 72.30 & 93.88 & -15.07 & 0.66 & 57.20 & 87.00 \\
\hline $12 / 15 / 96$ & 209.73 & 0.16 & 24.64 & 71.76 & 37.83 & 71.85 & 93.82 & -15.32 & 0.01 & 39.10 & 66.00 \\
\hline $12 / 16 / 96$ & 209.24 & 0.16 & 24.03 & 70.67 & 31.77 & 71.28 & 93.72 & -15.01 & 0.00 & 36.00 & 69.00 \\
\hline $12 / 17 / 96$ & 209.08 & 0.16 & 23.59 & 68.46 & 31.62 & 70.73 & 93.60 & -15.13 & 0.00 & 27.90 & 77.00 \\
\hline 12/18/96 & 208.83 & 0.15 & 22.90 & 65.02 & 29.74 & 69.71 & 93.44 & -15.31 & 0.00 & 20.60 & 60.00 \\
\hline $12 / 19 / 96$ & 208.96 & 0.15 & 22.15 & 62.50 & 29.89 & 68.65 & 93.24 & -15.35 & 0.00 & 18.50 & 63.00 \\
\hline $12 / 20 / 96$ & 209.28 & 0.15 & 21.54 & 61.72 & 32.57 & 67.90 & 92.99 & -15.22 & 0.00 & 30.10 & 54.00 \\
\hline $12 / 21 / 96$ & 209.39 & 0.15 & 21.02 & 62.94 & 44.20 & 67.73 & 92.82 & -14.87 & 0.00 & 48.10 & 68.00 \\
\hline $12 / 22 / 96$ & 209.77 & 0.14 & 20.88 & 66.06 & 57.39 & 68.11 & 92.68 & -14.86 & 0.00 & 62.60 & 75.00 \\
\hline $12 / 23 / 96$ & 209.50 & 0.14 & 20.77 & 68.22 & 56.15 & 68.53 & 92.73 & -14.90 & 0.00 & 50.40 & 72.00 \\
\hline $12 / 24 / 96$ & 209.24 & 0.14 & 20.39 & 65.24 & 35.63 & 68.16 & 92.78 & -15.42 & 0.00 & 23.70 & 60.00 \\
\hline $12 / 25 / 96$ & 209.23 & 0.14 & 19.90 & 63.53 & 32.19 & 67.62 & 92.72 & -15.24 & 0.00 & 33.50 & 57.00 \\
\hline $12 / 26 / 96$ & 209.35 & 0.14 & 19.62 & 65.60 & 39.59 & 67.71 & 92.57 & -14.98 & 0.00 & 41.70 & 64.00 \\
\hline $12 / 27 / 96$ & 209.45 & 0.14 & 19.46 & 65.33 & 44.00 & 67.73 & 92.53 & -14.93 & 0.00 & 44.40 & 80.00 \\
\hline $12 / 28 / 96$ & 209.61 & 0.14 & 19.40 & 66.75 & 51.58 & 67.91 & 92.48 & -14.86 & 0.00 & 54.60 & 77.00 \\
\hline $12 / 29 / 96$ & 209.54 & 0.14 & 19.22 & 67.56 & 43.34 & 68.10 & 92.48 & -15.09 & 0.00 & 46.90 & 69.00 \\
\hline $12 / 30 / 96$ & 209.42 & 0.14 & 19.05 & 69.90 & 48.65 & 68.43 & 92.53 & -15.15 & 0.00 & 56.00 & 83.00 \\
\hline $12 / 31 / 96$ & 209.52 & 0.14 & 19.14 & 70.39 & 53.64 & 68.83 & 92.62 & -15.19 & 0.00 & 55.40 & 92.00 \\
\hline $1 / 1 / 97$ & 209.94 & 0.14 & 19.26 & 71.01 & 54.33 & 69.07 & 92.70 & -15.08 & 0.00 & 59.80 & 91.00 \\
\hline $1 / 2 / 97$ & 209.82 & 0.14 & 19.08 & 72.18 & 55.88 & 69.33 & 92.78 & -14.95 & 0.00 & 63.80 & 83.00 \\
\hline $1 / 3 / 97$ & 209.79 & 0.14 & 19.08 & 72.90 & 57.59 & 69.76 & 92.91 & -14.68 & 0.00 & 68.00 & 77.00 \\
\hline $1 / 4 / 97$ & 209.95 & 0.14 & 19.10 & 73.57 & 50.20 & 70.08 & 93.04 & -14.72 & 0.00 & 60.60 & 60.00 \\
\hline $1 / 5 / 97$ & 209.56 & 0.13 & 18.75 & 71.78 & 37.63 & 70.03 & 93.08 & -15.20 & 0.00 & 42.40 & 52.00 \\
\hline $1 / 6 / 97$ & 209.15 & 0.13 & 18.55 & 69.31 & 32.59 & 69.65 & 93.06 & \begin{tabular}{|l|}
-15.44 \\
\end{tabular} & 0.00 & 33.00 & 50.00 \\
\hline $1 / 7 / 97$ & 209.18 & 0.13 & 18.18 & 67.18 & 29.67 & 69.03 & 92.89 & -15.44 & 0.00 & 35.00 & 40.00 \\
\hline $1 / 8 / 97$ & 209.13 & 0.13 & 17.48 & 65.88 & 35.33 & 68.60 & 92.71 & \begin{tabular}{|l|}
-15.13 \\
\end{tabular} & 0.00 & 32.50 & 81.00 \\
\hline $1 / 9 / 97$ & 209.26 & 0.13 & 17.33 & 65.16 & 39.89 & 68.26 & 92.53 & -14.93 & 0.44 & 35.00 & 79.00 \\
\hline $1 / 10 / 97$ & 209.36 & 0.12 & 16.79 & 63.88 & 32.48 & 67.84 & 92.43 & -15.15 & 0.00 & 25.10 & 53.00 \\
\hline $1 / 11 / 97$ & 209.15 & 0.12 & 16.50 & 61.50 & 29.10 & 67.10 & 92.33 & -15.44 & 0.00 & 16.80 & 56.00 \\
\hline $1 / 12 / 97$ & 209.33 & 0.12 & 15.90 & 59.50 & 29.72 & 66.26 & 92.17 & -15.68 & 0.00 & 15.70 & 67.00 \\
\hline $1 / 13 / 97$ & 209.02 & 0.12 & 14.96 & 64.72 & 22.75 & 65.96 & 91.91 & -15.75 & 0.00 & 18.10 & 61.00 \\
\hline $1 / 14 / 97$ & 209.08 & 0.11 & 14.76 & 72.78 & 17.45 & 67.03 & 91.87 & -15.39 & 0.00 & 26.30 & 60.00 \\
\hline $1 / 15 / 97$ & 209.16 & 0.11 & 14.79 & 76.28 & 20.54 & 68.06 & 91.88 & -14.95 & 0.02 & 34.70 & 71.00 \\
\hline $1 / 16 / 97$ & 208.97 & 0.11 & 14.48 & 77.10 & 15.32 & 68.84 & 91.98 & -15.54 & 0.00 & 23.10 & 48.00 \\
\hline $1 / 17 / 97$ & 209.39 & 0.11 & 14.38 & 76.81 & 13.28 & 69.07 & 91.93 & -15.52 & 0.00 & 22.40 & 48.00 \\
\hline $1 / 18 / 97$ & 209.62 & 0.11 & 14.39 & 77.98 & 14.87 & 69.48 & 91.88 & -15.36 & 0.00 & 30.60 & 53.00 \\
\hline $1 / 19 / 97$ & 209.52 & 0.11 & 14.38 & 80.11 & 18.50 & 70.14 & 91.88 & -15.19 & 0.00 & 42.90 & 59.00 \\
\hline $1 / 20 / 97$ & 209.54 & 0.11 & 14.39 & 82.31 & 23.67 & 70.95 & 91.88 & -15.09 & 0.00 & 50.60 & 77.00 \\
\hline $1 / 21 / 97$ & 209.46 & 0.11 & 14.44 & 84.78 & 32.36 & 71.97 & 92.00 & -14.90 & 0.01 & 60.60 & 88.00 \\
\hline $1 / 22 / 97$ & 209.41 & 0.11 & 14.49 & 86.04 & 24.50 & 72.75 & 92.18 & -14.98 & 0.00 & 52.70 & 62.00 \\
\hline
\end{tabular}




\begin{tabular}{|c|c|c|c|c|c|c|c|c|c|c|c|}
\hline Date & $\begin{array}{c}\text { AC } \\
\text { Volts }\end{array}$ & $\begin{array}{c}\text { AC } \\
\text { Amps }\end{array}$ & $\begin{array}{c}\text { DC Watts } \\
\text { (Computed) }\end{array}$ & $\begin{array}{l}\text { Rom } \\
\text { Temp }\end{array}$ & $\begin{array}{c}\text { Room } \\
\text { RH }\end{array}$ & $\begin{array}{l}\text { Wall } \\
\text { Temp }\end{array}$ & $\begin{array}{c}\text { Wall } \\
\text { RH }\end{array}$ & Well & Rainfall & $\begin{array}{c}\text { Outdoor } \\
\text { Temp } \\
\text { (Average) }\end{array}$ & $\begin{array}{c}\text { Outdoor RH } \\
\text { (Average) }\end{array}$ \\
\hline $1 / 23 / 97$ & 209.23 & 0.11 & 14.49 & 85.93 & 21.26 & 73.22 & 92.28 & -15.03 & 0.00 & 50.90 & 67.00 \\
\hline $1 / 24 / 97$ & 209.62 & 0.11 & 14.70 & 86.68 & 24.00 & 73.71 & 92.30 & -14.94 & 0.00 & 50.00 & 73.00 \\
\hline $1 / 25 / 97$ & 209.42 & 0.11 & 14.47 & 85.33 & 16.21 & 73.77 & 92.33 & -15.39 & 0.00 & 34.60 & 65.00 \\
\hline $1 / 26 / 97$ & 209.49 & 0.11 & 14.42 & 85.26 & 20.68 & 73.82 & 92.19 & -15.09 & 0.00 & 54.00 & 58.00 \\
\hline $1 / 27 / 97$ & 209.17 & 0.11 & 14.39 & 85.57 & 22.19 & 74.18 & 92.15 & -15.24 & 0.00 & 39.50 & 77.00 \\
\hline $1 / 28 / 97$ & 209.04 & 0.11 & 14.34 & 81.74 & 12.42 & 73.47 & 92.07 & -15.74 & 0.00 & 18.10 & 59.00 \\
\hline $1 / 29 / 97$ & 209.16 & 0.11 & 14.32 & 80.99 & 12.78 & 72.98 & 91.80 & -15.49 & 0.00 & 30.10 & 49.00 \\
\hline $1 / 30 / 97$ & 209.10 & 0.11 & 14.25 & 81.69 & 15.37 & 72.97 & 91.63 & -15.32 & 0.00 & 40.20 & 45.00 \\
\hline $1 / 31 / 97$ & 209.52 & 0.11 & 14.25 & 83.37 & 17.67 & 73.30 & 91.58 & -14.94 & 0.00 & 52.00 & 34.00 \\
\hline $2 / 1 / 97$ & 209.55 & 0.11 & 14.18 & 84.41 & 19.62 & 73.63 & 91.52 & -14.88 & 0.00 & 52.50 & 53.00 \\
\hline 2/2/97 & 209.52 & 0.11 & 14.12 & 85.77 & 20.80 & 73.98 & 91.48 & -15.04 & 0.00 & 53.80 & 55.00 \\
\hline 2/3/97 & 209.30 & 0.11 & 14.17 & 87.32 & 25.45 & 74.65 & 91.53 & -15.07 & 0.61 & 53.40 & 87.00 \\
\hline $2 / 4 / 97$ & 209.19 & 0.11 & 14.26 & 87.72 & 20.40 & 75.09 & 91.67 & -15.37 & 0.00 & 45.80 & 67.00 \\
\hline $2 / 5 / 97$ & 209.19 & 0.11 & 14.22 & 86.70 & 16.57 & 75.11 & 91.62 & -15.61 & 0.00 & 40.60 & 64.00 \\
\hline $2 / 6 / 97$ & 209.22 & 0.11 & 14.09 & 86.04 & 19.82 & 75.09 & 91.52 & -15.42 & 0.53 & 39.70 & 92.00 \\
\hline $2 / 7 / 97$ & 209.55 & 0.11 & 13.85 & 85.11 & 19.98 & 74.87 & 91.42 & -15.31 & 0.71 & 36.40 & 93.00 \\
\hline $2 / 8 / 97$ & 209.37 & 0.11 & 13.34 & 84.28 & 17.80 & 74.63 & 91.31 & -15.51 & 0.00 & 34.20 & 81.00 \\
\hline $2 / 9 / 97$ & 209.53 & 0.11 & 13.04 & 83.69 & 17.51 & 74.43 & 91.20 & -15.41 & 0.00 & 35.50 & 77.00 \\
\hline $2 / 10 / 97$ & 209.02 & 0.10 & 12.70 & 83.71 & 18.11 & 74.36 & 91.09 & -15.37 & 0.00 & 37.30 & 75.00 \\
\hline $2 / 11 / 97$ & 209.13 & 0.10 & 12.51 & 83.71 & 17.94 & 74.28 & 90.99 & -15.21 & 0.00 & 39.80 & 72.00 \\
\hline $2 / 12 / 97$ & 209.11 & 0.10 & 12.37 & 84.61 & 18.84 & 74.47 & 90.88 & -15.07 & 0.05 & 41.30 & 72.00 \\
\hline $2 / 13 / 97$ & 209.09 & 0.10 & 12.20 & 84.21 & 19.28 & 74.45 & 90.86 & -14.99 & 0.22 & 37.10 & 88.00 \\
\hline $2 / 14 / 97$ & 209.47 & 0.10 & 12.18 & 84.60 & 19.54 & 74.52 & 90.78 & -15.16 & 0.00 & 40.20 & 79.00 \\
\hline $2 / 15 / 97$ & 209.52 & 0.10 & 12.02 & 84.91 & 18.04 & 74.60 & 90.73 & -15.25 & 0.00 & 44.90 & 62.00 \\
\hline $2 / 16 / 97$ & 209.56 & 0.10 & 11.97 & 85.95 & 17.87 & 74.90 & 90.68 & \begin{tabular}{|l|}
-15.34 \\
\end{tabular} & 0.00 & 47.90 & 56.00 \\
\hline $2 / 17 / 97$ & 209.68 & 0.10 & 12.01 & 86.83 & 18.31 & 75.19 & 90.68 & \begin{tabular}{|l|}
-15.20 \\
\end{tabular} & 0.00 & 56.60 & 45.00 \\
\hline $2 / 18 / 97$ & 209.33 & 0.10 & 11.96 & 88.07 & 22.57 & 75.67 & 90.68 & -14.98 & 0.00 & 58.00 & 64.00 \\
\hline $2 / 19 / 97$ & 209.51 & 0.10 & 12.04 & 89.28 & 27.65 & 76.18 & 90.70 & \begin{tabular}{|l|}
-14.95 \\
\end{tabular} & 0.39 & 60.60 & 83.00 \\
\hline $2 / 20 / 97$ & 209.46 & 0.10 & 12.15 & 89.96 & 32.02 & 76.56 & 90.78 & \begin{tabular}{|l|}
-14.56 \\
\end{tabular} & 1.88 & 61.90 & 92.00 \\
\hline $2 / 21 / 97$ & 209.66 & 0.10 & 12.10 & 89.29 & 23.92 & 76.48 & 90.85 & \begin{tabular}{|l|}
-14.68 \\
\end{tabular} & 0.06 & 46.60 & 84.00 \\
\hline $2 / 22 / 97$ & 209.62 & 0.10 & 11.99 & 87.88 & 18.90 & 76.30 & 90.82 & \begin{tabular}{|l|}
-15.23 \\
\end{tabular} & 0.00 & 41.30 & 73.00 \\
\hline $2 / 23 / 97$ & 209.72 & 0.10 & 11.98 & 87.53 & 17.02 & 76.24 & 90.72 & \begin{tabular}{|l|}
-15.28 \\
\end{tabular} & 0.00 & 46.80 & 56.00 \\
\hline $2 / 24 / 97$ & 209.17 & 0.10 & 11.92 & 87.89 & 17.12 & 76.32 & 90.62 & -15.25 & 0.00 & 51.80 & 46.00 \\
\hline $2 / 25 / 97$ & 209.27 & 0.10 & 11.93 & 88.11 & 20.41 & 76.47 & 90.55 & -14.96 & 0.27 & 48.30 & 76.00 \\
\hline $2 / 26 / 97$ & 209.19 & 0.10 & 11.92 & 88.61 & 23.75 & 76.50 & 90.48 & \begin{tabular}{|l|}
-14.41 \\
\end{tabular} & 0.73 & 47.40 & 91.00 \\
\hline $2 / 27 / 97$ & 209.41 & 0.10 & 11.94 & 87.86 & 20.88 & 76.27 & 90.39 & -14.65 & 0.00 & 44.90 & 72.00 \\
\hline $2 / 28 / 97$ & 209.75 & 0.10 & 11.98 & 88.11 & 23.84 & 76.29 & 90.34 & -14.54 & 0.00 & 50.80 & 88.00 \\
\hline $3 / 1 / 97$ & 209.70 & 0.10 & 11.97 & 89.54 & 28.73 & 76.62 & 90.34 & \begin{tabular}{|l|}
-14.60 \\
\end{tabular} & 0.00 & 58.70 & 84.00 \\
\hline $3 / 2 / 97$ & 209.69 & 0.10 & 11.97 & 88.66 & 20.54 & 76.67 & 90.38 & -14.78 & 0.17 & 42.40 & 78.00 \\
\hline $3 / 3 / 97$ & 209.33 & 0.10 & 11.93 & 88.71 & 20.72 & 76.56 & 90.32 & \begin{tabular}{|c|}
-14.64 \\
\end{tabular} & 0.00 & 50.30 & 67.00 \\
\hline $3 / 4 / 97$ & 209.36 & 0.10 & 11.93 & 90.50 & 23.02 & 77.02 & 90.28 & \begin{tabular}{|l|}
-14.66 \\
\end{tabular} & 0.00 & 62.70 & 54.00 \\
\hline $3 / 5 / 97$ & 209.20 & 0.10 & 11.91 & 89.54 & 17.94 & 77.12 & 90.33 & \begin{tabular}{|l|}
-15.03 \\
\end{tabular} & 0.00 & 42.50 & 62.00 \\
\hline $3 / 6 / 97$ & 209.23 & 0.10 & 11.91 & 88.54 & 16.58 & 76.91 & 90.22 & -15.19 & 0.00 & 46.30 & 53.00 \\
\hline $3 / 7 / 97$ & 209.50 & 0.10 & 11.94 & 88.76 & 17.55 & 76.95 & 90.12 & -14.96 & 0.00 & 50.80 & 50.00 \\
\hline $3 / 8 / 97$ & 209.65 & 0.10 & 11.95 & 89.46 & 23.22 & 77.13 & 90.06 & -14.90 & 0.10 & 53.30 & 88.00 \\
\hline $3 / 9 / 97$ & 209.63 & 0.10 & 11.94 & 90.42 & 28.22 & 77.40 & 90.08 & \begin{tabular}{|l|}
-14.84 \\
\end{tabular} & 0.21 & 59.90 & 78.00 \\
\hline $3 / 10 / 97$ & 209.31 & 0.10 & 11.91 & 90.39 & 20.64 & 77.51 & 90.11 & \begin{tabular}{|l|}
-14.84 \\
\end{tabular} & 0.00 & 54.70 & 60.00 \\
\hline $3 / 11 / 97$ & 209.41 & 0.10 & 11.89 & 90.94 & 22.05 & 77.69 & 90.08 & -14.76 & 0.00 & 58.80 & 64.00 \\
\hline
\end{tabular}




\begin{tabular}{|c|c|c|c|c|c|c|c|c|c|c|c|}
\hline Date & $\begin{array}{c}\mathrm{AC} \\
\text { Volts }\end{array}$ & $\begin{array}{c}\text { AC } \\
\text { Amps } \\
\end{array}$ & $\begin{array}{c}\text { DC Watts } \\
\text { (Computed) }\end{array}$ & $\begin{array}{l}\text { Rom } \\
\text { Temp } \\
\end{array}$ & $\begin{array}{c}\text { Room } \\
\text { RH }\end{array}$ & $\begin{array}{l}\text { Wall } \\
\text { Temp }\end{array}$ & $\begin{array}{c}\text { Wall } \\
\mathrm{RH} \\
\end{array}$ & Well & Rainfall & $\begin{array}{c}\text { Outdoor } \\
\text { Temp } \\
\text { (Average) }\end{array}$ & $\begin{array}{c}\text { Outdoor RH } \\
\text { (Average) }\end{array}$ \\
\hline $3 / 12 / 97$ & 209.33 & 0.10 & 11.87 & 91.65 & 22.82 & 78.00 & 90.08 & -14.74 & 0.58 & 56.50 & 77.00 \\
\hline $3 / 13 / 97$ & 209.37 & 0.10 & 11.90 & 91.74 & 28.85 & 78.16 & 90.08 & -14.44 & 0.52 & 57.60 & 93.00 \\
\hline $3 / 14 / 97$ & 209.50 & 0.10 & 111.79 & 89.32 & 18.24 & 77.78 & 90.06 & -14.94 & 0.00 & 38.30 & 58.00 \\
\hline $3 / 15 / 97$ & 209.40 & 0.10 & 11.59 & 87.61 & 15.60 & 77.39 & 89.97 & -15.09 & 0.00 & 39.20 & 50.00 \\
\hline $3 / 16 / 97$ & 209.50 & 0.10 & 111.08 & $\begin{array}{l}87.34 \\
\end{array}$ & 18.89 & 77.13 & 89.79 & -14.93 & 0.00 & 44.50 & 55.00 \\
\hline $3 / 17 / 97$ & 209.33 & 0.10 & 10.79 & 87.78 & 26.71 & 77.06 & 89.64 & -14.69 & 0.00 & 57.10 & 85.00 \\
\hline $3 / 18 / 97$ & 209.29 & 0.09 & 10.64 & 89.23 & 29.76 & 77.38 & 89.67 & -14.68 & 0.00 & 58.70 & 83.00 \\
\hline $3 / 19 / 97$ & 209.14 & 0.09 & 10.51 & 88.52 & 21.44 & 77.38 & 89.74 & -14.89 & 0.04 & 41.10 & 86.00 \\
\hline 3/20/97 & 209.12 & 0.09 & 10.15 & 88.21 & 21.52 & 77.19 & 89.62 & -14.68 & 0.00 & 52.50 & 65.00 \\
\hline $3 / 21 / 97$ & 209.65 & 0.09 & 10.25 & 90.49 & 23.14 & 77.55 & 89.58 & -14.44 & 0.00 & 68.70 & 46.00 \\
\hline $3 / 22 / 97$ & 209.74 & 0.09 & 10.18 & 91.56 & 18.65 & 78.00 & 89.67 & -14.68 & 0.00 & 57.50 & 45.00 \\
\hline $3 / 23 / 97$ & 209.73 & 0.09 & 10.13 & 91.88 & 18.19 & 78.24 & 89.62 & -14.70 & 0.00 & 58.90 & 47.00 \\
\hline $3 / 24 / 97$ & 209.48 & 0.09 & 10.44 & 92.16 & 22.25 & 78.46 & 89.56 & -14.59 & 0.00 & 68.20 & 54.00 \\
\hline $3 / 25 / 97$ & 209.66 & 0.10 & 11.45 & 91.86 & 24.44 & 78.36 & 89.50 & -14.71 & 0.77 & 52.30 & 72.00 \\
\hline $3 / 26 / 97$ & 209.32 & 0.10 & 11.75 & 90.13 & 17.39 & 77.79 & 89.47 & -14.95 & 0.00 & 49.40 & 59.00 \\
\hline $3 / 27 / 97$ & 209.34 & 0.10 & 11.13 & 91.25 & 21.62 & 78.18 & 89.38 & -14.60 & 0.00 & 61.60 & 57.00 \\
\hline $3 / 28 / 97$ & 209.83 & 0.10 & 10.83 & 92.32 & 23.67 & 78.67 & 89.42 & -14.41 & 0.00 & 63.70 & 54.00 \\
\hline $3 / 29 / 97$ & 209.73 & 0.09 & 10.40 & 92.55 & 19.25 & 78.91 & 89.45 & -14.60 & 0.15 & 62.10 & 49.00 \\
\hline $3 / 30 / 97$ & 209.81 & 0.09 & 10.29 & 92.62 & 18.49 & 79.16 & 89.44 & -14.91 & 0.00 & 53.10 & 59.00 \\
\hline $3 / 31 / 97$ & 209.33 & 0.09 & 10.06 & 91.88 & 16.44 & 79.11 & 89.35 & -14.97 & 0.00 & 55.20 & 44.00 \\
\hline 4/1/97 & 209.39 & 0.09 & 9.98 & 92.03 & 16.95 & 79.20 & 89.27 & -14.81 & 0.00 & 62.20 & 37.00 \\
\hline $4 / 2 / 97$ & 209.30 & 0.09 & 9.78 & 92.41 & 21.54 & 79.33 & 89.18 & -14.86 & 0.00 & 65.90 & 49.00 \\
\hline $4 / 3 / 97$ & 209.55 & 0.09 & 10.01 & 87.11 & 27.91 & 79.17 & 89.21 & -14.72 & 0.09 & 65.70 & 46.00 \\
\hline $4 / 4 / 97$ & 210.12 & 0.09 & 9.80 & $\begin{array}{l}79.47 \\
\end{array}$ & 47.66 & 77.78 & 89.06 & -14.32 & 0.76 & 62.70 & 92.00 \\
\hline 4/5/97 & 210.04 & 0.09 & 9.39 & 77.10 & 46.44 & 76.55 & 88.92 & -14.29 & 0.18 & 63.80 & 59.00 \\
\hline $4 / 6 / 97$ & 210.10 & 0.09 & 9.22 & 75.33 & 40.39 & 75.62 & 88.82 & -14.86 & 0.00 & 51.40 & 47.00 \\
\hline $4 / 7 / 97$ & 209.79 & 0.09 & 9.19 & 73.58 & 40.52 & 74.80 & 88.72 & -15.03 & 0.00 & 53.90 & 52.00 \\
\hline $4 / 8 / 97$ & 209.70 & 0.09 & 9.18 & 72.42 & 39.22 & 74.13 & 88.62 & -14.98 & 0.20 & 50.00 & 73.00 \\
\hline $4 / 9 / 97$ & 209.57 & 0.09 & 9.16 & 69.92 & 39.75 & 73.27 & 88.52 & -15.03 & 0.00 & 49.60 & 80.00 \\
\hline 4/10/97 & 209.61 & 0.09 & 9.17 & 69.60 & 40.38 & 72.66 & 88.33 & -14.75 & 0.00 & 61.70 & 55.00 \\
\hline $4 / 11 / 97$ & 209.97 & 0.09 & 9.20 & 69.67 & 44.33 & 72.32 & 88.28 & -14.63 & 0.88 & 49.00 & 83.00 \\
\hline 4/12/97 & 209.72 & 0.09 & 9.15 & 66.76 & 35.98 & 71.28 & 88.15 & -14.92 & 0.00 & 35.90 & 68.00 \\
\hline $4 / 13 / 97$ & 209.91 & 0.09 & 9.17 & 65.20 & 35.03 & 70.58 & 88.03 & -14.98 & 0.00 & 39.40 & 65.00 \\
\hline $4 / 14 / 97$ & 209.29 & 0.09 & 8.92 & 64.93 & 36.90 & 70.01 & 87.87 & -14.96 & 0.00 & 47.70 & 57.00 \\
\hline $4 / 15 / 97$ & 209.70 & 0.09 & 8.72 & 65.80 & 38.30 & 69.80 & 87.75 & -14.91 & 0.00 & 56.30 & 51.00 \\
\hline $4 / 16 / 97$ & 209.67 & 0.08 & 8.45 & 67.91 & 42.19 & 69.81 & 87.69 & -14.96 & 0.04 & 52.40 & 83.00 \\
\hline 4/17/97 & 209.71 & 0.08 & 8.66 & 68.75 & 38.68 & 69.93 & 87.72 & -14.93 & 0.00 & 55.90 & 62.00 \\
\hline $4 / 18 / 97$ & 210.03 & 0.08 & 8.32 & 68.37 & 44.40 & 69.86 & 87.75 & -14.67 & 0.00 & 62.30 & 62.00 \\
\hline 4/19/97 & 210.01 & 0.08 & 8.08 & 69.16 & 50.37 & 69.89 & 87.78 & -14.53 & 0.00 & 65.30 & 67.00 \\
\hline $4 / 20 / 97$ & 210.26 & 0.08 & 8.18 & 70.24 & 51.83 & 70.02 & 87.83 & -14.45 & 0.02 & 68.90 & 69.00 \\
\hline $4 / 21 / 97$ & 209.92 & 0.08 & 8.23 & 71.24 & 50.80 & 70.23 & 87.95 & -14.44 & 0.00 & 64.40 & 72.00 \\
\hline $4 / 22 / 97$ & 209.40 & 0.08 & 7.96 & 71.29 & 45.85 & 70.36 & 88.06 & -14.55 & 0.29 & 60.30 & 68.00 \\
\hline $4 / 23 / 97$ & 209.11 & 0.08 & 7.45 & 69.85 & 40.27 & 70.21 & 88.08 & -14.68 & 0.00 & 53.50 & 71.00 \\
\hline $4 / 24 / 97$ & 209.38 & 0.08 & 7.38 & 68.40 & 41.62 & 69.87 & 88.09 & -14.79 & 0.09 & 51.60 & 76.00 \\
\hline $4 / 25 / 97$ & 209.71 & 0.08 & 7.16 & 67.71 & 45.50 & 69.70 & 88.08 & -14.92 & 0.64 & 51.50 & 85.00 \\
\hline $4 / 26 / 97$ & 209.84 & 0.07 & 6.64 & 66.83 & 50.35 & 69.38 & 88.05 & -14.87 & 0.26 & 52.00 & 92.00 \\
\hline $4 / 27 / 97$ & 209.78 & 0.07 & 6.30 & 66.51 & 50.45 & 69.12 & 87.98 & -14.73 & 0.05 & 54.00 & 81.00 \\
\hline $4 / 28 / 97$ & 209.41 & 0.07 & 6.10 & 66.92 & 48.88 & 68.97 & 87.98 & -14.65 & 0.00 & 57.20 & 65.00 \\
\hline
\end{tabular}




\begin{tabular}{|c|c|c|c|c|c|c|c|c|c|c|c|}
\hline Date & $\begin{array}{c}\text { AC } \\
\text { Volts }\end{array}$ & $\begin{array}{c}\text { AC } \\
\text { Amps }\end{array}$ & $\begin{array}{c}\text { DC Watts } \\
\text { (Computed) }\end{array}$ & $\begin{array}{c}\text { Rom } \\
\text { Temp }\end{array}$ & $\begin{array}{c}\text { Room } \\
\text { RH }\end{array}$ & $\begin{array}{c}\text { Wall } \\
\text { Temp }\end{array}$ & $\begin{array}{c}\text { Wall } \\
\text { RH }\end{array}$ & Well & Rainfall & $\begin{array}{c}\text { Outdoor } \\
\text { Temp } \\
\text { (Average) }\end{array}$ & $\begin{array}{c}\text { Outdoor RH } \\
\text { (Average) }\end{array}$ \\
\hline $4 / 29 / 97$ & 209.31 & 0.07 & 6.09 & 67.76 & 54.01 & 68.95 & 88.03 & -14.66 & 0.00 & 65.30 & 66.00 \\
\hline $4 / 30 / 97$ & 209.18 & 0.07 & 6.07 & 68.80 & 54.62 & 69.08 & 88.10 & -14.60 & 0.00 & 65.10 & 65.00 \\
\hline
\end{tabular}


USACERL Distribution

Chief of Engineers

ATTN: CEHEC-IM-LH (2)

ATTN: CEHEC-IM-LP (2)

ATTN: CECG

ATTN: CECC-P

ATTN: CECC-R

ATTN: CECW

ATTN: CECW-O

ATTN: CECW-P

ATTN: CECW-PR

ATTN: CEMP

ATTN: CEMP-E

ATTN: CEMP-C

ATTN: CEMP-M

ATTN: CEMP-R

ATTN: CERD-C

ATTN: CERD-ZA

ATTN: CERD-L

ATTN: CERD-M (2)

ACS(IM) 22060

ATTN: DAIM-FDP

CECPW 22310-3862

ATTN: CECPW-E

ATTN: CECPW-FT

ATTN: CECPW-ZC

US Army Engr District

ATTN: Library (42)

US Army Engr Division

ATTN: Library (8)

US Army Europe

ATTN: AEAEN-EH 09014

ATTN: AEAEN-ODCS 09014

29th Area Support Group

ATTN: AEUSG-K-E 09054

222d BSB Unit \#23746

ATTN: AETV-BHR-E 09034

235th BSB Unit \#28614

ATTN: AETV-WG-AM 09177

293d BSB Unit \#29901

ATTN: AEUSG-MA-E 09086

409th Support Battalion (Base)

ATTN: AETTG-DPW 09114

412th Base Support Battalion 09630

ATTN: Unit 31401

221st Base Support Battalion

ATTN: Unit 2962309096

CMTC Hohenfels 09173

ATTN: AETTH-SB-DPW

Mainz Germany 09185

ATTN: AETV-MNZ-E

21st Support Command

ATTN: DPW (8)

SETAF

ATTN: AESE-EN-D 09613

ATTN: AESE-EN 09630

Supreme Allied Command

ATTN: ACSGEB 09703

ATTN: SHIHB/ENGR 09705

INSCOM

ATTN: IALOG-I 22060

ATTN: IAV-DPW 22186

USA TACOM 48397-5000

ATTN: AMSTA-XE

Defense Distribution Region East

ATTN: ASCE-WI 17070-5001

Defense Distribution Region West ATTN: ASCW-WG 95296-0100

HQ XVIII Airborne Corps 28307

ATTN: AFZA-DPW-EE

US Army Materiel Command (AMC)
Alexandria, VA 22333-0001
ATTN: AMCEN-F ATTN: AMXEN-C 61299-
7190
Installations: (20)
FORSCOM
Forts Gillem \& McPherson 30330
ATTN: FCEN
Installations: (20)
TRADOC
Fort Monroe 23651
ATTN: ATBO-G
Installations: (20)
Fort Belvoir 22060
ATTN: CETEC-IM-T

ATTN: Water Resources Support Ctr

USA Natick RD\&E Center 01760

ATTN: STRNC-DT

ATTN: AMSSC-S-IMI

US Army Materials Tech Lab

ATTN: SLCMT-DPW 02172

USARPAC 96858

ATTN: DPW

ATTN: APEN-A

SHAPE 09705

ATTN: Infrastructure Branch LANDA

Area Engineer, AEDC-Area Office

Arnold Air Force Station, TN 37389

HQ USEUCOM 09128

ATTN: ECJ4-EN

CEWES 39180

ATTN: Library

CECRL 03755

ATTN: Library

USA AMCOM

ATTN: Facilities Engr 21719

ATTN: AMSMC-EH 61299

ATTN: Facilities Engr (3) 85613

USAARMC 40121

ATTN: ATZIC-EHA

Military Traffic Mgmt Command

ATTN: MT-LOF 22041-5000

ATTN: MTE-SU-FE 28461

Fort Leonard Wood 65473

ATTN: ATSE-DAC-LB (3)

ATTN: ATZT

ATTN: ATSE-CFLO

ATTN: ATSE-DAC-FL

ATTN: Australian Liaison Office

Military Dist of WASH

Fort McNair

ATTN: ANEN-IS 20319

USA Engr Activity, Capital Area

ATTN: Library 22211

US Army ARDEC 07806-5000

ATTN: AMSTA-AR-IMC

Engr Societies Library

ATTN: Acquisitions 10017
US EPA, Region $V$

ATTN: AFRC-ENIL-FE 60561

US Army Environmental Center ATTN: SFIM-AEC-NR 21010

ATTN: SFIM-AEC-CR 64152

ATTN: SFIM-AEC-SR 30335-6801

ATTN: AFIM-AEC-WR 80022-2108

Defense Nuclear Agency

ATTN: NADS 20305

Defense Logistics Agency

ATTN: MMBIR 22060-6221

National Guard Bureau 20310

ATTN: NGB-ARI

US Military Academy 10996

ATTN: MAEN-A

ATTN: Facilities Engineer

ATTN: Geography \& Envr Engrg

Naval Facilities Engr Command

ATTN: Facilities Engr Command (8)

ATTN: Engrg Field Divisions (10)

ATTN: Engrg Field Activities (4)

ATTN: Public Works Center (8)

ATTN: Naval Constr Battalion Ctr 93043

ATTN: Naval Facil. Engr. Service Ctr 93043-4328

8th US Army Korea

ATTN: DPW (11)

USA Japan (USARJ)

ATTN: APAJ-EN-ES 96343

ATTN: HONSHU 96343

ATTN: DPW-Okinawa 96376

416th Engineer Command 60623

ATTN: Gibson USAR Ctr

US Army MEDCOM

ATTN: MCFA 78234-6000

Fort Detrick 21702-5000

ATTN: MCHS-IS

Fort Sam Houston 78234-5000

ATTN: MCFA-PW

Walter Reed Army Medical Center 20007-5001 ATTN: MCHL-PW

Tyndall AFB 32403

ATTN: HQAFCESA/CES

ATTN: Engrg \& Srvc Lab

USA TSARCOM 63120

ATTN: STSAS-F

American Public Works Assoc. 64104-1806

US Army CHPPM

ATTN: MCHB-DE 21010

US Gov't Printing Office 20401

ATTN: Rec Sec/Deposit Sec (2)

Nat'l Institute of Standards \& Tech

ATTN: Library 20899

Defense General Supply Center ATTN: DGSC-WI 23297-5000

Defense Supply Center Columbus ATTN: DSCC-WI 43216-5000

Defense Tech Info Center 22060-6218

ATTN: DTIC-O (2)

$$
276
$$

